\title{
Part of a Scientific Master Plan? Paul Ehrlich and the Origins of his Receptor Concept
}

\author{
CAY-RÜDIGER PRÜLL*
}

One of the basic theories of twentieth-century scientific medicine is the receptor concept. It deals with the question of how information can be submitted to the cell. Receptors can be described as "small, discrete area(s) on the cell membrane or within the cell with which molecules or molecular complexes (for example, hormones, drugs, and other chemical messengers) interact". ${ }^{1}$ The receptor concept became increasingly important, especially for pharmacology, as it explained the binding of drugs to cells and drug-effects on specific tissues and organs.

The origins of the receptor concept stem from the last third of the nineteenth century and are chiefly connected with two names: Paul Ehrlich (1854-1915) and John Newport Langley (1852-1925). Remarkably, these two scientists approached the receptor idea on significantly different routes and from different backgrounds: John Newport Langley, professor of physiology in Cambridge, was predominantly concerned with the investigation of the functions of the autonomic nervous system, i.e. of those nerves which regulate, without our conscious influence, the vegetative functions of the body, such as blood-pressure and respiration. Paul Ehrlich, the Berlin bacteriologist and immunologist, was keen to examine the relations between bacterial toxins and antitoxins and to support contemporary efforts to combat infectious diseases. Both mentioned the idea first in 1878, and both returned to their former approaches only several years later-at the turn of the nineteenth to the twentieth century. According to our current knowledge about the history of the receptor concept, the two scientists developed their initial ideas on receptors independently. ${ }^{2}$

\section{* Cay-Rüdiger Prüll, PhD, Wolfson Research Institute, University of Durham, Queen's Campus, Stockton University Boulevard, Thornaby, Stockton on Tees TS17 6BH, UK.}

This paper is a first product of the Wellcome Trust funded research project, 'The impact of the receptor concept on twentieth-century pharmacology', which is being undertaken by Professor Andreas-Holger Maehle, Dr Robert Halliwell, and myself. It is my special concern to thank both my colleagues for their advice and suggestions, and the Wellcome Trust for its support. I would also like to thank the Rockefeller Foundation for a grant to visit the Rockefeller Archive Center in New York.

${ }^{1}$ Black's medical dictionary, ed. Gordon MacPherson, 39th ed., London, A \& C Black, 1999, p. 463.

\footnotetext{
${ }^{2}$ For current views on the history of the receptor concept, see Arthur Silverstein, Paul Ehrlich's receptor immunology: the magnificent obsession, San Diego and London, Academic Press, 2002; John Parascandola and Ronald Jasensky, 'Origins of the receptor theory of drug action', Bull. Hist.Med., 1974, 48: 199-220; John Parascandola, 'The development of receptor theory', in M J Parnham and J Bruinvels (eds), Discoveries in pharmacology, vol. 3, Pharmacological methods, receptors and chemotherapy, Amsterdam and New York, Elsevier Science Publishers, 1986, pp. 129-56; Max R Bennett, 'The concept of transmitter receptors: 100 years on', Neuropharmacology, 2000, 19: 523-46. On Langley, see Gerald L Geison, 'Langley, John Newport', in Dictionary of scientific biography, New York, Charles Scribner's Sons, 1973, vol. 8, pp. 14-19; Walter Morley Fletcher, 'John Newport Langley: in memoriam', J. Physiol., 1926, 61: 1-27.
} 


\section{Paul Ehrlich and his Receptor Concept}

This paper focuses on Paul Ehrlich and the development of his receptor concept between 1878 and approximately 1905, when the concept was brought to a certain conclusion. The purpose is to deal with a basic problem: as there are two independent approaches to the subject, one could assume that receptors are "objective" facts of nature and that the "discovery" of the receptors was somehow "inevitable". This impression contrasts with the sociological constructivist interpretation of science: discoveries do not neatly correspond to objective entities in nature. They are dependent on the cultural setting, for example, the social position of the researcher and the local scientific system. ${ }^{3}$ This paper will show that the constructivist view can be helpful in understanding Ehrlich's "discovery" of the receptor concept as the latter emerged from the dual effect of social and scientific aspects of his biography. This means that although the roots of Ehrlich's ideas can be traced back to early stages of his career, although his ideas appeared in a logical order and although he was driven by a leitmotif throughout his academic life, it was far from clear why and how he would develop the receptor concept. My analysis provides some insights into the history of modern medical science and contributes to our understanding of the receptor concept's position in early twentieth-century medicine. In this context it is not my purpose to follow up the history of the usage of Ehrlich's concept in pharmacology. By contrast, I envisage this paper as a contribution to the analysis of the difficult starting position of the receptor idea. Its birth and its character contain the roots of problems, which caused many difficulties in the successful introduction of the idea to pharmacology after 1945.

I will first discuss Ehrlich's basic scientific ideas and the traditional views on his academic life. Then I will go into more detail and take a close look at Ehrlich's career in relation to his work on receptors. Finally, I will summarize and evaluate my findings. ${ }^{4}$

\section{The Roots of Ehrlich's Research and the Inevitable Discovery of the Receptors}

In any focused analysis of Ehrlich's ideas, the introduction of his receptor concept appears to be consistently planned and realized. As a medical student at the universities of Strasbourg and Breslau he concentrated on the staining of histological specimens. Breslau became especially important: he was influenced above all by the pathologist Julius Cohnheim (1839-1884), one of the few German pathologists to use animal experimentation in addition to pathological anatomy. ${ }^{5}$ Cohnheim's research into pathological function, in

\footnotetext{
${ }^{3}$ For the constructivist view of the history of science, see Jan Golinski, Making natural knowledge: constructivism and the history of science, Cambridge University Press, 1998; Timothy Lenoir, Instituting science: the cultural production of scientific disciplines, Stanford University Press, 1997.

${ }^{4}$ This paper makes use of the printed works of Ehrlich between 1878 and 1905, which can be found in Fred Himmelweit (ed.), with the assistance of Martha Marquardt, under the editorial direction of Sir Henry Dale, The collected papers of Paul Ehrlich in four volumes including a complete bibliography, vol. 1, Histology, biochemistry and pathology, vol. 2, Immunology and cancer research; vol. 3,

Chemotherapy, London and New York, Pergamon
} Press, 1956-60; and of parts of Ehrlich's unpublished estate, his laboratory books, his laboratory notes and his correspondence in the Paul Ehrlich Collection, Rockefeller University Archives at the Rockefeller Archive Center in New York (hereafter RUA, RAC). The paper also considers materials from the Archive of the Humboldt-University in Berlin and from the State Archive of Prussian Cultural Heritage (Geheimes Staatsarchiv PreuBischer Kulturbesitz, hereafter GStA PK), Berlin.

${ }_{5}$ Ernst Bäumler, Paul Ehrlich. Forscher für das Leben, 3rd ed., Frankfurt am Main, Wötzel, 1997, pp. 24-30, 31-6; Ernst Jokl, 'Paul Ehrlich: man and scientist', Bull. N. Y. Acad. Med., 1954, 30: 968-75, esp. p. 972; Margaret Goldsmith, 'Paul Ehrlich', in Hector Bolitho (ed.), Twelve Jews, London, Rich \& Cowan, 1934, pp. 65-81, esp. p. 69. 


\section{Cay-Rüdiger Prüll}

contrast to pathological morphology, was accompanied by close contacts with clinicians. He also influenced many British medical students and contributed in this way to the introduction of "clinical pathology" into Britain. ${ }^{6}$ Under his influence, Ehrlich followed the path of applying laboratory findings to clinical practice and, in fact, became a pioneer of clinical pathology in Germany.

Ehrlich's basic scientific ideas can be briefly summarized: first, he made a claim for the routine application of the method of staining to medicine in general and to histology in particular. Second, he supported the theory that the staining process relied on a chemical reaction between dye-stuff and cell. ${ }^{7}$ These two ideas formed the basis or leitmotif of Ehrlich's side-chain and then receptor theory. As early as 1878 Ehrlich had written in his dissertation of "a definite chemical character of the cell" 8 which was necessary for its reaction with a dye. In 1897, almost nineteen years later, when he worked on immunological problems, Ehrlich returned to this point and developed his chemical "side-chain theory". Certain "side-chains" of the cell were able to bind certain toxins. Because these occupied side-chains would then become unable to fulfil their physiological functions, the cell would overcompensate by producing a lot of additional side-chains, which would be released into the blood-stream, where they acted as antibodies or antitoxins. ${ }^{9}$ Against this background, in 1900, Ehrlich introduced the term "receptor" as a designation of the side-chain's function. ${ }^{10}$ In 1908, Ehrlich was awarded the Nobel Prize for his work in immunology.

A shift in thinking enabled Ehrlich to apply his concept to drug binding. He first thought receptors would bind toxines and nutritive substances only. Many drugs could be extracted from tissues easily and so they seemingly could not be bound firmly to the cell. Therefore they could not evoke the production of side-chains. ${ }^{11}$ Ehrlich's theory allowed-as a future perspective-drug binding to cells only indirectly, as he proposed that certain chemical bodies or groups (Körperklassen) with specific binding capacities to specific organs could be used as "vehicles" (Lastwagen) to carry artificial substances to the site of effect. ${ }^{12}$ Not before 1907-with reference to his own work on the effect of dyes on trypanosomes and

\footnotetext{
${ }^{6}$ Cay-Rüdiger Prüll, Medizin am Toten oder am Lebenden? Pathologie in Berlin und in London 1900 bis 1945, Freiburg, 1999, Habilitation thesis, Basle, Schwabe, forthcoming; esp. pp. 389-92; Russell C Maulitz, 'Rudolf Virchow, Julius Cohnheim, and the program of pathology', Bull. Hist. Med., 1978, 52: 162-82.

${ }^{7}$ Concerning Ehrlich and chemistry, see Henry Hallett Dale, 'Introduction', in Himmelweit (ed.), vol. 1, op. cit., note 4 above, pp. 1-18, esp. p. 2; Goldsmith, op. cit., note 5 above, pp. 69-70.

8 “... eine bestimmte chemische Beschaffenheit der Zelle selbst ...", in Paul Ehrlich, Beiträge zur Theorie und Praxis der histologischen Färbung, Thesis, Leipzig University, 1878, in Himmelweit (ed.), vol. 1, op. cit., note 4 above, pp. 29-64, English transl.: ibid., pp. 65-98. See the quotation on p. 40 (German original); p. 75 (English transl.).

${ }^{9}$ Paul Ehrlich, 'Die Wertbemessung des Diphtherieheilserums und deren theoretische Grundlagen' (Klinisches Jahrbuch, 1897), in Himmelweit (ed.), vol. 2, op. cit., note 4 above, pp. 86-106, English transl. pp. 107-25. For a
}

contemporary description of Ehrlich's side-chain theory, see Ludwig Aschoff, Ehrlich's Seitenkettentheorie und ihre Anwendung auf die künstlichen Immunisierungsprozesse, Jena, Fischer, 1902, esp. pp. 1-25. See also Bruno Heymann, 'Zur Geschichte der Seitenkettentheorie Paul Ehrlichs', Klin. Wochenschr., 1928, 7: 1257-60; Arthur M Silverstein, A history of immunology, San Diego and New York, Academic Press, 1989, esp. pp. 64-6, 94-9.

${ }^{10}$ Paul Ehrlich and Julius Morgenroth, 'Über Haemolysine. Dritte Mittheilung' (Berliner Klinische Wochenschrift, 1900), in Himmelweit (ed.), vol. 2, op. cit., note 4 above, pp. 196-204, English transl. pp. 205-12.

${ }^{11}$ John Parascandola, 'The theoretical basis of Paul Ehrlich's chemotherapy', J. Hist. Med. Allied Sci., 1981, 36: 19-43, esp. p. 28.

${ }^{12}$ Paul Ehrlich, 'Über die Beziehung von chemischer Constitution, Vertheilung und pharmakologischer Wirkung', from Internationale Beiträge zur inneren Medizin: Festschrift für Ernst $v$. Leyden zur Feier seines 70. jährigen Geburtstages 
Langley's notion of "receptive substances"- did Ehrlich accept the binding of drugs to receptors. ${ }^{13}$ For this purpose there would be specific "chemoreceptors". The drug needed to have a greater affinity to the chemoreceptors of the invading organisms, for example the trypanosomes, than to the chemoreceptors of the host's body. The concept of "specific affinity" was applied to the pharmacological realm. Based on early nineteenth-century investigations of the relationship between chemical composition and physiological action of certain drugs, ${ }^{14}$ Ehrlich was now able to explain all the phenomena in connection with the effect of a chemotherapeutic drug, for example drug resistance, with the help of the receptor concept. The receptors became the theoretical basis for his subsequent work with the dye "trypan red" and with the arsenic compound "atoxyl" to combat trypanosome infections, ending with the discovery of Salvarsan, the first chemotherapeutic substance for the treatment of syphilis, in $1910 .{ }^{15}$ With this discovery, Ehrlich became one of the most prominent figures of twentieth-century medicine. ${ }^{16}$

The development and realization of Ehrlich's theories quickly acquired the appearance of an unbroken success story, taking three steps in a constituent order: stainingimmunology - chemotherapy. ${ }^{17}$ Of course, the hypothetical character of the side-chain and receptor theory was soon acknowledged, but its development within the frame of Ehrlich's life and career was described as an undisturbed homogeneous process of maturing, sometimes as the successive appearance of secretly predeveloped plans. This interpretation did not remain unchallenged, but it shaped the historiography on Ehrlich's work. ${ }^{18}$ Even in Ehrlich's own time, ${ }^{19}$ the side-chain or receptor theory found its place in his celebrated biography. In 1919, one of his students, Leonor Michaelis, was impressed by the newly discovered dissertation of the master. It would be "of great value for the recognition of Ehrlich's scientific development". According to Michaelis, the dissertation foreshadowed

am 20. April 1902, Berlin, Hirschwald, 1902, in Himmelweit (ed.), vol. 1, op. cit., note 4 above, pp. 570-95, esp. p. 595. English transl. pp. 596-618, esp. p. 618.

${ }^{13}$ Parascandola, op. cit., note 2 above, pp. 134-41.

${ }^{14}$ See William F Bynum, 'Chemical structure and pharmacological action: a chapter in the history of 19th century molecular pharmacology, Bull. Hist. Med., 1970, 44: 518-38.

${ }^{15}$ It is not possible in this paper to give a full account of the history of the application of the receptor concept to drug binding and pharmacology. See, esp., Parascandola, op. cit., note 11 above, pp. 21, $30-3,35$.

${ }^{16}$ The best general account of Ehrlich's life is Claude E Dolman, 'Paul Ehrlich', in Dictionary of scientific biography, New York, Charles Scribner's Sons, 1981, vol. 3, pp. 295-305. Dolman also gives an overview of the literature on Ehrlich up to 1980. Although eighty-six years have passed since his death, the writing on Ehrlich remains largely hagiographic (see, for example, Bäumler, op. cit., note 5 above) for several reasons. As Ehrlich was Jewish, all public written testimonies of his life were erased by the Nazi government after 1933. After the war, Ehrlich's estate was not accessible for research until recently.

Furthermore, hagiographic accounts were presumably promoted by the new scientific optimism of the postwar decades, for example, Ernst Witebsky, 'Ehrlich's side-chain theory in the light of present immunology', Ann. N. Y. Acad.Sci., 1954, 59: 168-81. For the history of research on Ehrlich, see Henry Hallett Dale, 'Introduction', in Martha Marquardt, Paul Ehrlich, London, Heinemann, 1949, pp. xiii-xx; Dale, op. cit., note 7 above above; Bäumler, op. cit, note 5 above, pp. 5-9. The serious recent historiography of Ehrlich includes mostly papers on specific aspects of his work.

${ }^{17}$ See, for example, Richard Koch, 'Vorwort', in Martha Marquardt, Paul Ehrlich als Mensch und Arbeiter. Erinnerungen aus dreizehn Jahren seines Lebens (1902-1915), Stuttgart and Berlin, DVA, 1924, pp. 3-15; Dale, 'Introduction', op. cit., note 16 above, p. xvi.

${ }^{18} \mathrm{See}$, for example, Jokl, op. cit., note 5 above, p. 974; F Klose, 'Paul Ehrlich und Emil v. Behring. Zur hundertjährigen Wiederkehr ihrer Geburtstage am 14. und 15. März 1954', Deutsche Med. Wochenschr., 1954, 79: 425-27, esp. p. 425.

${ }^{19}$ See August von Wassermann, 'Die Seitenkettentheorie', in Hugo Apolant et al., Paul Ehrlich. Eine Darstellung seines wissenschaftlichen Wirkens. Festschrift zum 60. Geburtstage des Forschers (14. März 1914), Jena, Gustav Fischer, 1914, pp. 134-50. 


\section{Cay-Rüdiger Prüll}

Ehrlich's whole oeuvre. ${ }^{20}$ Even today, Ehrlich's dissertation is sometimes regarded as the master plan of a successful research programme. ${ }^{21}$ Recent papers on his work, which do not venture extensively into Ehrlich's biography and the circumstances of his life, explicitly or implicitly defend the view of a continuous path towards the receptors. Anthony S Travis explains the development of the side-chain and receptor idea as an outcome of Ehrlich's progressive work on dyes. Considering the "social frameworks" for him means a focus on Ehrlich's collaboration with the chemical industry. Timothy Lenoir's interpretation lies in the same direction. It focuses on the position of Ehrlich's research on the side-chains within the triangle of science, politics, and industry. In 1999, Arthur M Silverstein drew a more radical conclusion from his analysis of Ehrlich's "receptor immunology". According to him, the receptor idea had been pursued by Ehrlich from his dissertation onwards for over twenty years, i.e. up to 1898. In his monograph on Ehrlich's receptor concept, Silverstein's argument is basically the same. ${ }^{22}$ The studies of John Parascandola and Ronald Jasensky aptly describe the ups and downs of the early receptor theory, but do not explore its social, historical and cultural context. ${ }^{23}$

A closer look into the development of the concept in the context of Ehrlich's biography until 1905 shows us the impact of many more factors on the emergence of his idea. In analysing Ehrlich's development of the receptor theory within the framework of his socialization and academic career, five phases can be detected.

\section{Paul Ehrlich's Scientific Career and the Emergence of his Receptor Concept}

\section{(1) Ehrlich as a Clinician, 1878-1888}

In 1909, a few years before his death, Ehrlich informed a friend about the most important aspects of his scientific work. He pointed out that his greatest interest had always been in active therapeutics and that the combination of his chemical and therapeutic interests could explain his entire scientific career. ${ }^{24}$ In 1878 , Ehrlich was appointed senior physician at the First Medical Clinic of the Charite-Hospital in Berlin. The head of the clinic at this time was the well-known professor of internal medicine, Friedrich Theodor Frerichs (1819-1885). ${ }^{25}$

20 “.... zur Erkennung der wissenschaftlichen Entwicklung Ehrlichs sehr wertvoll", see Leonor Michaelis, 'Zur Erinnerung an Paul Ehrlich: Seine wiedergefundene Doktor-Dissertation', Die Naturwissenschaften, 1919, 7: 165-8, esp. p. 165; see also pp. 167-8.

${ }^{21}$ Maria Luise Eckmann, Die Doktorarbeit Paul Ehrlichs und ihre Bedeutung für die Geschichte der histologischen Färbung, Thesis, Hamburg University, 1959; Liz Marshall, 'Paul Ehrlich. 1854-1915. German bacteriologist and immunologist', in Emily $\mathbf{J}$

McMurray (ed.), Kelly Kosek and Roger M Valade III (assoc. eds), Notable twentieth-century scientists, New York and London, Gale Research, 1995, vol. 1, pp. 564-7, esp. p. 565.

${ }^{22}$ Anthony S Travis, 'Science as the receptor of technology: Paul Ehrlich and the synthetic dyestuffs industry', Science in Context, 1989, 3: 383-408; Timothy Lenoir, 'A magic bullet: research for profit and the growth of knowledge in Germany around 1900', Minerva, 1988, 26: 66-88; Arthur M Silverstein, 'Paul Ehrlich's passion: the origins of his receptor immunology', Cell. Immunol., 1999, 194: 213-21; Silverstein, op. cit., note 2 above.

${ }^{23}$ Parascandola and Jasensky, op. cit., note 2 above, pp. 199-220; Parascandola, op. cit., note 2 above, pp. 129-56. Also concentrating mainly on Ehrlich's ideas, Anne-Marie Moulin, Le dernier langage de la médecine. Histoire de l'immunologie de Pasteur au Sida, Paris, Presses Universitaires de France, 1991, esp. pp. 74-97.

${ }^{24}$ Dale, op. cit., note 7 above above, p. 9.

${ }^{25}$ Franz Hermann Franken, Friedrich Theodor Frerichs (1819-1885). Leben und hepatologisches Werk, Freiburg , Falk Foundation, 1994; M Classen, F H Franken, D Gericke, 'Friedrich Theodor Frerichs in Berlin', Deutsche Med. Wochenschr., 1995, 120: 1334-7. 


\section{Paul Ehrlich and his Receptor Concept}

Frerichs wanted to integrate laboratory research and laboratory diagnostics into clinical work in the wards, and he therefore supported Ehrlich's staining experiments. ${ }^{26}$ In the following years, Ehrlich combined his work in the wards with his work at the laboratory bench. He performed pathoanatomical studies, examining tissue specimens from the postmortem room to gain knowledge about the causes of patient deaths. The application of staining methods helped to explain the pathologically altered function of the morphological structures. One example of this research is Ehrlich's study of glycogen in the healthy and in the diabetic human organism. ${ }^{27}$

Moreover, Ehrlich worked in the field of clinical pathology when examining body fluids of living patients. One example is his study of bacteriological problems in the course of pleuritic exudates (effusions into the pleural cavity) through consideration of the patient records of women in childbed. The application of different staining methods on microbes allowed him to identify different infections. These results enabled him to give diagnostic and prognostic advice. ${ }^{28}$ Furthermore, in these years under Frerichs, Ehrlich performed the first biopsies of the liver on humans. ${ }^{29}$ Finally, he described the so-called Diazo-reaction (Diazo-Reaktion) in 1883. This was a special urine test to detect bilirubin with the help of dyes-a clinical test for patients with presumably heavy infections. ${ }^{30}$

Only occasionally did Ehrlich publish single clinical case histories, which show only a marginal relation to his scientific work. ${ }^{31}$ Most of the papers written in these clinical years are concerned with the application of dyes, especially in animal experiments. In 1882 , Ehrlich examined fluorescent dyes on the eye of the rabbit, hoping to find a method to diagnose human eye diseases. The effectiveness of the substance as well as possible side effects were of interest. ${ }^{32}$ Ehrlich's experiments on blood were especially outstanding. Following animal experimentation, different dyes were applied and tested on the blood of sick and healthy patients. Different kinds of white and red blood cells were explored. This experimental work was then applied to the diagnosis and therapy of blood- and infectious diseases. Ehrlich became a pioneer in modern haematology. ${ }^{33}$ Furthermore, Ehrlich's early co-operation with the bacteriologist Robert Koch (1843-1910) relied on the use of staining

\footnotetext{
${ }^{26}$ Travis, op. cit., note 22 above, p. 393.

${ }^{27}$ Dolman, op. cit., note 16 above, p. 296; Paul Ehrlich, 'Über das Vorkommen von Glykogen im diabetischen und im normalen Organismus' (Zeitschrift für klinische Medizin, 1883), in Himmelweit (ed.), vol. 1, op. cit., note 4 above, pp. 103-12.

${ }^{28}$ Paul Ehrlich, 'Beiträge zur Ätiologie und Histologie pleuritischer Exsudate', (Charité-Annalen, 1882), in Himmelweit (ed.), vol. 1, op. cit., note 4 above, pp. 290-310.

${ }^{29}$ Franken, op. cit., note 25 above, pp. 59-62.

${ }^{30}$ Paul Ehrlich, 'Über eine neue Harnprobe', (Charité-Annalen, 1883), in Himmelweit (ed.), vol. 1, op. cit., note 4 above, pp. 619-29; idem, 'Sulfodiazobenzol, ein Reagenz auf Bilirubin' (Zentralblatt für klinische Medizin, 1883), in ibid. pp. 630-1; idem, 'Über die Sulfodiabenzol-Reaction' (Zentralblatt für klinische Medizin, 1883), in ibid., pp. 632-42; idem, 'Nachträgliche Bemerkungen zur Diazoreaction' (Charité-Annalen, 1886), in ibid., pp.
}

643-5; idem, 'Die Diazo- und Azomethin-Reactionen', draft, probably written in 1900, in ibid., pp. 646-50; idem, 'Über die Dimethylamidobenzaldehydreaction' (Medizinische Woche, 1901), in ibid., pp. 651-3.

${ }^{31}$ See, for example, a case study on phosphorous poisoning: Paul Ehrlich, 'Über einen Fall von Phosphorvergiftung mit symmetrischer Gangraena pedum' (Charité-Annalen, 1882), in Himmelweit (ed.), vol. 1 , op. cit., note 4 , pp. 526-9.

${ }^{32}$ Paul Ehrlich, 'Über provocirte

Fluorescenzerscheinungen am Auge' (Deutsche Medizinische Wochenschrift, 1882), in Himmelweit (ed.), vol. 1, op. cit., note 4 above, pp. 344-53.

${ }^{33}$ For an overview, see Paul Ehrlich and A Lazarus, Histology of the blood, Cambridge University Press, 1900 (rev. transl. of P Ehrlich and A Lazarus, 'Die Anaemie', in $\mathrm{H}$ Nothnagel, Specielle Pathologie und Therapie, Vienna, Hölder, 1898), in Himmelweit (ed.), vol. 1, op. cit., note 4 above, pp. 181-268. 


\section{Cay-Rüdiger Prüll}

as an instrument to serve practical purposes. After 1882, when Koch had demonstrated the newly found tubercle bacillus, Ehrlich improved Koch's staining method for this microbe. ${ }^{34}$

Ehrlich used dyes not only to solve problems of diagnosis but also to introduce them as therapeutic agents. In 1886, the substance thallin was used on rabbits and shortly thereafter on patients suffering from typhoid fever. The best dosage to combat the fever symptoms was estimated, particularly at the climax of the disease. Ehrlich was able to give advice on the clinical use of this substance. ${ }^{35}$

Ehrlich's profile of daily work enables us to estimate the impact of the receptor concept on his research at these times. The "side-chain" theory was the outcome of one specific study - his habilitation thesis (teaching licence) of 1885 , which was dedicated to Frerichs. On the basis of countless animal experiments, Ehrlich wanted to estimate the "oxygen-need of the organism" (Sauerstoff-Bedürfniss des Organismus). The dyes served him to indicate the different degrees of oxygen affinity of the various organs. Following the infusion of dyes, the animals were killed after certain intervals of time, and dissected. The colouring of the tissues indicated the metabolic activities of the single organs and tissues and enabled a certain classification. Ehrlich concluded that the inner part of the cell (protoplasm/ Protoplasma) was able to utilize oxygen. According to Ehrlich, the protoplasm had side-chains, which could bind oxygen. This complex could be burned in the protoplasm and transformed into energy. His study presented a theoretical basis for his staining methods, but the side-chain as predecessor of the receptor played no important role in his discussion of oxygen utilization. Moreover, Ehrlich focused on the organs, the character of the protoplasm and of the surrounding paraplasm (Paraplasma, more unspecific areas of the cell, die mehr indifferenten Territorien des Zellenleibes) of the cell. ${ }^{36}$ The side-chains are mentioned in Ehrlich's 69-page habilitation thesis (in Himmelweit's edition of the collected works) only six times and then never again during the period of his work under Frerichs. ${ }^{37}$

Ehrlich's major aim was to achieve clinically applicable results. He could influence the work on the wards when connecting different fields: staining methods, animal experimentation, clinical work and human therapeutic experiments. This filled Ehrlich's entire working time. Remarkably, he achieved his aims without any deeper insights into the exact way in which substances bind to cells. This explains why there was no discussion of the side-chains in the years after the publication of his habilitation thesis. In 1891 Ehrlich was still calling himself a "clinician", ${ }^{38}$ and he had acquired his teaching licence in the field of "practical

\footnotetext{
${ }^{34}$ Paul Ehrlich, 'Modification der von Koch angegebenen Methode der Färbung von Tuberkelbazillen'(Deutsche Medizinische Wochenschrift, 1882), in Himmelweit (ed.), vol. 1, op. cit., note 4 above, pp. 311-13; idem, 'Referat über die gegen R. Koch's Entdeckung der Tuberkelbacillen neuerlichst hervorgetretenen Einwände' (Deutsche Medizinische Wochenschrift, 1882), in ibid., vol. 1, pp. 322-9.

${ }^{35}$ Paul Ehrlich, 'Experimentelles und Klinisches über Thallin' (Deutsche Medizinische Wochenschrift, 1886), in Himmelweit (ed.), vol. 1, op. cit., note 4 above, pp. 542-51.
}

\footnotetext{
${ }^{36}$ Paul Ehrlich, Das Sauerstoff-Bedürfniss des Organismus. Eine farbenanalytische Studie (Habilitation thesis), Berlin, Hirschwald, 1885, in Himmelweit (ed.), vol. 1, op. cit., note 4 above, pp. 364-432, esp. p. 415. English transl. on pp. 433-96.

${ }^{37}$ Ibid., pp. 368, 419, 422, 430 (German original).

${ }_{38}$ Paul Ehrlich, Zur Geschichte der Granula, repr. from Farbenanalytische Untersuchungen zur Histologie und Klinik des Blutes, Berlin, Hirschwald, 1891, in Himmelweit (ed.), vol. 1, op. cit., note 4 above, pp. 166-68, esp. 166 .
} 


\section{Paul Ehrlich and his Receptor Concept}

and clinical medicine" (praktische Medicin und ärztliche Klinik) ${ }^{39}$ And in 1898, when together with a colleague he published the results of their research on the blood cells, he pointed out the importance of clinical examination. When describing the place of origin of the white blood cells, Ehrlich wrote that it would be "hard to avoid errors if one confines oneself exclusively to animal experiments without supplementing these by clinical experience ... Not the anatomist, not the physiologist, but only the clinician is in a position to discuss these problems". ${ }^{40}$ And furthermore: why did he not apply his now published idea of side-chains to the haematological results, even though they were concerned with metabolic and microbiological problems, such as the effect of bacterial poisons on white blood cells? ${ }^{41}$ Ehrlich was mostly devoted to laboratory work but it made sense for him only in connection with practical medicine: he tried to improve diagnostic techniques and tools to make them usable even for the untrained physician walking the wards.

These two aims mentioned by Ehrlich later as most important-chemistry as well as its application to biological problems and practical therapy-could initially be reached without any detailed knowledge about receptors. Moreover, private as well as professional matters were developing. In 1883 Ehrlich married, and in 1884 his parents moved from Strehlen in Upper Silesia to Berlin. ${ }^{42}$ In the very same year, Ehrlich became a titular "professor". 43

\section{(2) The Change of Emphasis, 1889-1895}

Ehrlich's situation changed rapidly after Frerichs' death in 1885 . Now he worked under Carl Gerhardt (1833-1902), Frerichs' successor as head of the Second Medical Clinic of the Charite in Berlin. Gerhardt was mainly interested in clinical work in the wards, not in the attached laboratories. He focused on the development of clinical diagnostics and on the organization of empirical studies on patients, and he integrated Ehrlich into the daily clinical routine. There is enough evidence that this caused Ehrlich severe trouble as he remained a devoted laboratory worker. He was diagnosed as tuberculous in 1888 , resigned and went to Egypt to recover. Leaving his position in Berlin was a break in his career, particularly because as, a Jew, he could not obtain a full professorship or employment at a State Institute. Every step of his scientific career, which was achieved only by troublesome efforts, had to be maintained if he wished to gain a respected social position. ${ }^{44}$

\footnotetext{
${ }^{39}$ Note, in Acta der Friedrich-WilhelmsUniversität Berlin, Habilitationen von 1880-1889, Medizinische Fakultät-Dekanat, No.1342/1, p. 203, Archive of the Humboldt University, Berlin.

${ }^{40}$ Ehrlich and Lazarus, op. cit., note 33 above, p. 213.

${ }^{41}$ Ibid., p. 258.

${ }^{42}$ Bäumler, op. cit., note 5 above, pp. 60,68 . See Margaret Goldsmith's remark on Ehrlich's life after his appointment to Frerichs' clinic: "The next seven or eight years were one of the most fruitful and satisfying periods of Ehrlich's life", in Goldsmith, op. cit., note 5 above, p. 71.

${ }^{43}$ Goldsmith, ibid., p. 72. The view expressed in the British Medical Journal concerning Ehrlich's work at
}

\begin{abstract}
Frerichs' clinic, that practical clinical work did not suit Ehrlich, is one of the rare comments on this topic in the literature. See 'Obituary. Professor Paul Ehrlich', Br.med.J., 1915, ii: 349 . For his time with Frerichs, see Dolman, op. cit., note 16 above, pp. 296-7.

${ }^{44}$ Goldsmith, op. cit., note 5 above, pp. 73-4; Dolman, op. cit., note 16 above, p. 297. For Carl Gerhardt, see his obituary 'Professor Carl Gerhardt', Lokal-Anzeiger, 1902, 20: No. 337, Berlin, 22 July 1902, p. 1; in Acta betr. die Anstellung des Geheimen Medicinal Raths und Professors Dr. Gerhardt als dirigirender Arzt und Director der 2. medicinischen Universitäts-klinik, 1885, Kgl. Charité-Direction, No. 437, p. 37, Archive of the Humboldt-University, Berlin.
\end{abstract}




\section{Cay-Rüdiger Prüll}

Ehrlich returned to Berlin in $1889 .^{45}$ He was unemployed and could set up a small laboratory only with the financial help of his father-in-law. He no longer had any patients. Now he had to rely solely on his dyes and animal experimentation. Ehrlich turned to immunological work. The latter was not least inspired by Koch and contemporary ideas about anti-bacterial treatments, and above all by Koch's assistant Emil von Behring (1854 1917) who, together with his co-worker Shibasaburo Kitasato (1852-1931), discovered the phenomenon of antitoxin in diphtheria and tetanus in $1890 .{ }^{46}$ Ehrlich was successful in immunizing mice against the plant poisons, ricin and abrin; he investigated the suggested hereditary transmission of immunity and its transmission via breast feeding; he got results on the basic processes of active and passive immunization. ${ }^{47}$

In 1890, only one year later, the period of private science ended because Koch offered his former assistant a post as clinical supervisor for scientific studies on tuberculosis at the City Hospital Berlin-Moabit. Now Ehrlich was able to take up clinical experimentation again, as he had done during his time with Frerichs, and he again combined it with animal experimentation and histological investigation in the laboratory. Indeed, Koch gave him a small laboratory and a few assistants. ${ }^{48}$ Together with a colleague, he explored the best tolerated dosage of the tuberculin serum and combined therapeutic human experimentation with histological sputum examinations. ${ }^{49}$ And he again worked with dyes in analysing the analgesic effect of methylene-blue. These trials were performed on prisoners at the Imperial Prison Moabit (Königliche Strafanstalt Moabit) and the associated Observation Unit for Insane Criminals (Beobachtungsanstalt für geisteskranke Verbrecher). The result was that the dye methylene-blue was observed to have an effect on certain types of pain, above all on migraine. ${ }^{50}$ Methylene-blue was also tested as a therapeutic agent against malaria. ${ }^{51}$ In 1891 , Koch offered him his own laboratory in the newly founded Institute for Infectious Diseases (Institut für Infektionskrankheiten). This was a good opportunity for Ehrlich to start a close co-operation with the bacteriological group working under Koch, which included Behring, Richard Pfeiffer (1858-1945), and August Wassermann (1866-1925). Ehrlich's interest in immunology grew enormously. Above all, the ability of the organism to form substances (i.e. antibodies) to combat specific microbes seemed to be useful in developing new treatments: the therapeutic sera. From 1891, therefore, Ehrlich worked chiefly on human immunology. Although the investigation of dyes and clinical tests moved

\footnotetext{
${ }^{45}$ Marquardt, op. cit., note 16 above, pp. 27-8; Bäumler, op. cit., note 5 above, pp. 68-9.

${ }^{46}$ Jonathan Liebenau, 'Paul Ehrlich as a commercial scientist and research administrator', Med. Hist., 1990, 34: 65-78, esp. p. 66.

${ }^{47}$ Paul Ehrlich, 'Experimentelle Untersuchungen über Immunität I. Über Ricin' (Deutsche Medizinische Wochenschrift, 1891), in Himmelweit (ed.), vol. 2, op. cit., note 4 above, pp. 21-6; idem, 'Experimentelle Untersuchungen über Immunität II. Über Abrin' (Deutsche Medizinische Wochenschrift, 1891), in ibid., pp. 27-30; idem, 'Über Immunität durch Vererbung und Säugung' (Zeitschrift für Hygiene und Infektionskrankheiten, 1892), in ibid., pp. 31-44. See, Adolf Lazarus, Paul Ehrlich, Vienna and Berlin, Rikola, 1922, pp. 34-5.
}

\footnotetext{
${ }^{48}$ Goldsmith, op. cit., note 5 above, p. 76.

${ }^{49}$ Dolman, op. cit., note 16 above, p. 297; Paul Ehrlich, Paul Guttmann, 'Die Wirksamkeit kleiner Tuberkulindosen gegen Lungenschwindsucht' (Deutsche Medizinische Wochenschrift, 1891), in Himmelweit (ed.), vol. 2, op. cit., note 4 above, pp. 7-12.

${ }^{50}$ Paul Ehrlich and A Leppmann, 'Über schmerzstillende Wirkung des Methylenblau' (Deutsche Medizinische Wochenschrift, 1890), in Himmelweit (ed.), vol. 1, op. cit., note 4 above, pp. 555-8.

${ }^{51}$ Paul Ehrlich and Paul Guttmann, 'Über die Wirkung von Methylenblau bei Malaria' (Berliner Klinische Wochenschrift, 1891), in Himmelweit (ed.), vol. 3, op. cit., note 4 above, pp. 9-14.
} 


\section{Paul Ehrlich and his Receptor Concept}

into the background, they continued to play a role in his daily work. Diphtheria serum, for example, was tested on children. 52

\section{(3) Ehrlich as a Theorizer, 1895-1905}

Ehrlich remained in a dependent position and his fate was again decided by his association with Koch and by a sponsor outside the Institute. At the request of Behring, Ehrlich turned again to investigate theoretical problems of immunity. Behring and the Hoechst company (Farbwerke Hoechst, near Frankfurt am Main) had difficulties with the production of the new therapeutic diphtheria serum. Before 1894 it was not possible to make it in reliable concentrations. As in the case of tuberculin, the challenge was to standardize the effective dosage. Behring asked Ehrlich for help and, considering the keen competition in Koch's Institute, one can assume that it was only "the direct request of Behring, urged on by an impatient Koch and a cost-conscious Hoechst Company, that would allow Ehrlich to venture into an area to which his institute colleague had full priority claim". 53 Behring agreed with Ehrlich that the latter should examine the exact quantitative relations between diphtheria toxin and antitoxin and develop a method to standardize the application of the therapeutic serum. ${ }^{54}$

The research on the diphtheria serum helped to put Ehrlich's scientific career onto a socially secure basis. In Koch's Institute, Ehrlich never got an official post because of his Jewish faith. ${ }^{55}$ When in 1895 the "control station" for therapeutic sera (Controlstation für Heilsera) was opened in the Institute, Ehrlich became only the deputy head of the department, whereas the responsibility for its work was handed over to Koch's assistants August Wassermann and Hermann Kossel. ${ }^{56}$ Eventually, however, the influence of the powerful

\footnotetext{
${ }^{52}$ See the descriptions of the clinical trials in Paul Ehrlich, Hermann Kossel and August Wassermann, 'Über Gewinnung und Verwendung des Diphtherieheilserums' (Deutsche Medizinische Wochenschrift, 1894), in Himmelweit (ed.), vol. 2, op. cit., note 4 above, pp. 56-60, esp. pp. 57-60; Paul Ehrlich and Hermann Kossel, 'Über die Anwendung des Diphtherieantitoxins' (Zeitschrift für Hygiene und Infektionskrankheiten, 1894), in ibid., pp. 61-2.

${ }^{3}$ Silverstein, op. cit., note 2 above, p. 42 . Although Silverstein's monograph on Ehrlich's receptor concept is almost exclusively devoted to the history of ideas, it gives occasional hints of the importance of the social setting for the development of Ehrlich's career and the receptor concept.

${ }^{54}$ Bäumler, op. cit., note 5 above, pp. 90-3. Dolman, op. cit., note 16 above, p. 297. For Ehrlich and his early involvement in the development of serum therapy against diphtheria, see Ehrlich, Kossel and Wassermann, op. cit., note 52 above; Ehrlich and Kossel, op. cit., note 52 above; Paul Ehrlich and A Wassermann, 'Über die Gewinnung der DiphtherieAntitoxine aus Blutserum und Milch immunisirter Thiere' (Zeitschrift für Hygiene und Infektionskrankheiten, 1894), in Himmelweit (ed.), vol. 2, op. cit., note 4 above, pp. 72-9; Paul Ehrlich,
}

'Über Gewinnung, Werthbestimmung und

Verwerthung des Diphtherieheilserums' (Hygienische Rundschau, 1894), in ibid., pp. 80-3.

${ }^{55}$ Goldsmith, op. cit., note 5 above, p. 76 . In the report on the work of Koch's Institute of 1892, Ehrlich is mentioned only once as a voluntary assistant. See 'Ueber den Bericht des Koch'schen Instituts für Infectionskrankheiten', Leipzig, Thieme, 1892 (offprint from Deutsche Medizinische Wochenschrift, No. 4-7 (1892)), in Acta betr. die Einrichtung und die Verwaltung des (staatlichen) Institutes für Infektionskrankheiten in Berlin, vom Januar 1892 bis Dezember 1898, in GStA PK. I. HA, Rep.76 Kultusministerium, VIII B, No. 2893, pp. 63-75, esp. p. 71. In the records of Koch's Institute, kept by the Berlin Charité-Hospital for the years 1893 to 1895 , Ehrlich's name does not appear at all. See Acta betr. das Institut für Infectionskrankheiten, Kgl. CharitéDirection., No. 2205, 1893-1895, Archive of the Humboldt-Univerity of Berlin.

${ }^{56}$ The Prussian Minister of Science and Education to Robert Koch, 9 Feb. 1895; Bericht über die Thätigkeit des Kgl. Instituts für Serumforschung und Serumprüfung zu Steglitz. Juni 1896-September 1899. Zur Einweihung des Königl. Instituts für experimentelle Therapie Frankfurt/M., Jena, Fischer, 1899, in Acta 


\section{Cay-Rüdiger Prüll}

and well-known Ministry Councillor in the Prussian Ministry of Science and Education (Ministerialrat im preußischen Kultusministerium), Friedrich Althoff (1839-1908), saved Ehrlich from all the problems and difficulties of his provisional post. Ehrlich and Althoff knew each other very well and also had private contacts. ${ }^{57}$ It was Althoff who promoted Ehrlich's career further and who mainly organized the institutional framework of his academic life. Ehrlich was grateful, as he believed his academic colleagues judged him "unusable". 58 A safe social position was a priority and had to be secured. This was so important that Ehrlich's wife even wrote to Althoff. She was very interested in promoting her husband's career, and was still trying to secure an independent position for him in 1903, when the main decisions on Ehrlich's institutional setting had already been made. ${ }^{59}$ The challenge of the diphtheria serum brought Ehrlich this independence. At the instigation of Althoff, he became, in 1896, Head of the new Institute for Serum Research and Serum Testing (Institut für Serumforschung und Serumprüfung) in Steglitz in the suburbs of Berlin. $^{60}$ Its main purpose was the testing of sera, but it also enabled Ehrlich to focus on diphtheria research in the laboratory.

The events and outcome described led to Ehrlich's second predominantly theory-oriented phase of work, and instigated the creation of his "side-chain" and "receptor-theory". Although relevant as an explanatory tool for his research, the "side-chains" had been mentioned in only two of his papers between 1885 (the year of the development of his theory) and $1897 .{ }^{61}$ In his classical study, 'The assay of the activity of diphtheria-curative serum and its theoretical basis' (1897), ${ }^{62}$ Ehrlich now defined the side-chains as a part of an immunological system. He tried to find a standard dosage for the application of diphtheria antitoxin. He tested a vast number of diphtheria toxins of different origin on guinea pigs and discovered two threshold concentrations. The first was a completely neutralized solution of toxins, which caused no signs of disease when applied to a guinea pig. The second contained the quantity of toxin that killed a 250-gram animal within four days. The difference between

betr. das Institut für experimentelle Therapie zu Frankfurt a.M., vom Februar 1895 bis Dezember 1900, GStA PK. I. HA, Rep.76 Kultusministerium, Vc Sekt.1, Tit.XI, Teil II, No. 18, vol.1; pp. 1, 189-203, 203.

${ }^{57}$ For Friedrich Althoff, see Bernhard vom Brocke (ed.), Wissenschaftsgeschichte und Wissenschaftspolitik im Industriezeitalter. Das "System Althoff" in historischer Perspektive, Hildesheim, Lax, 1991; idem, 'Hochschul- und Wissenschaftspolitik in Preußen und im Deutschen Kaiserreich 1882-1907: das "System Althoff", in Peter Baumgart (ed.), Bildungspolitik in Preußen zur Zeit des Kaiserreichs, Stuttgart, Klett-Cotta, 1980, pp. 9-118.

${ }^{58}$ Paul Ehrlich to Friedrich Althoff, 27 July 1907 , in Nachlass Althoff B, GstA PK. VI. HA, Rep. 92, No. 33, pp. 217-22, esp. p. 219. See also Wolfgang U Eckart, 'Friedrich Althoff und die Medizin', in vom Brocke, op. cit., note 57 above, pp. 375-404, on Ehrlich, see esp. pp. 398-401.

${ }^{59} \mathrm{See}$, for example, Hedwig Ehrlich to Friedrich Althoff, 13 Sept. 1903, in Nachlass Althoff B, ibid., pp. 71-4; Goldsmith, op. cit., note 5 above, p. 74. This is not the place to discuss the difficulties between Ehrlich and Behring. They are described and analysed in the secondary literature on Ehrlich.

${ }^{60}$ Goldsmith, op. cit., note 5 above, pp. 77-8.

${ }^{61}$ Paul Ehrlich, 'Studien in der Cocainreihe' (Deutsche Medizinische Wochenschrift, 1890), in Himmelweit (ed.), vol. 1, op. cit., note 4 above, pp. 559-66; idem, 'Über neuere Erfahrungen in der Behandlung der Tuberkulose nach Koch, insbesondere der Lungenschwindsucht' (Transactions of the 7th International Congress of Hygiene and Demography, 1891), in ibid., vol. 2, op. cit., note 4 above, pp. 13-20.

${ }^{62}$ Ehrlich, 'Die Wertbemessung des Diphtherieheilserums', op. cit., note 9 above, pp. 86106; see the English translation on pp. 107-25. The quotations in the following footnotes refer to the German original. For the impact of this paper on Britain, see also H G Plimmer, 'A critical summary of Ehrlich's recent work on toxins and antitoxins', J. Pathol. Bacteriol., 1897, 5: 489-98. 


\section{Paul Ehrlich and his Receptor Concept}

the first (neutral) and the final (lethal) solution was called the "single lethal dose" (einfache letale Dosis). ${ }^{63}$ Ehrlich's results were far from encouraging, as the concentrations of the solutions of the different diphtheria toxins varied markedly. Moreover, the solutions were not stable, but lost their toxicity after a certain period of storage, although the number of antibody-binding units did not decrease. This meant that the toxic effect did not correspond with the capacity of the toxin to bind to antitoxin. The only explanation for this phenomenon was that the toxins themselves had undergone some changes. ${ }^{64}$ Forced to explain these results, Ehrlich came back to his "side-chain theory". The toxin was thought to consist of two parts: a poisonous component, the so-called "toxophore group" (toxophore Gruppe), and a component that enabled the binding to the antitoxin, the so-called "haptophore group" (haptophore Gruppe). According to Ehrlich, the toxophore group was not as stable as the haptophore group and in consequence the toxophore groups successively dissolved. Therefore, to a certain extent toxins emerged which were able to bind antitoxins, but which no longer had a toxic effect. Ehrlich called these poisons "toxoids" (Toxoide). Through that binding capacity to a side-chain of the cell, these toxoids were able to induce the production of antibodies: the latter were an overcompensated production of side-chains, which were released into the blood-stream. This meant that chemical processes of specific binding were combined with biological processes of regeneration. Ehrlich explained the binding mechanism with the analogy that the biochemist Emil Fischer (1852-1919) had used to describe the effect of enzymes when he wrote about the "key-lock" mechanism. ${ }^{65}$ With his paper of 1897, Ehrlich expanded his vague and provisional idea of side-chains to a "side-chain theory". From now on, this theory was the basis of his immunological investigations. Ehrlich's work became theory-oriented, and immunological studies dominated his research for the next few years. ${ }^{66}$

\section{(4) From the "Side-Chains" to the Receptors}

In the following years, Ehrlich's side-chain theory became more and more intricate as its details were studied experimentally. Between 1897 and 1905, these experiments were carried out with vast effort and extensive use of different animal species and poisonous substances. Until 1899, this took place in the Steglitz Institut, ${ }^{67}$ thereafter in the Institute for Experimental Therapy (Institut für Experimentelle Therapie) in Frankfurt am Main. The

\footnotetext{
${ }^{63}$ Ehrlich, op. cit., note 9 above, pp. 89-93.

${ }^{64}$ Ibid., pp. 93, 96. See also Lazarus, op. cit., note 47 above, p. 36.

${ }^{65}$ Ehrlich, op. cit., note 9 above, pp. 93-106 (immunological theory), p. 94 (key-lock mechanism); Heymann, op. cit., note 9 above, p. 1258. For the history of the "key-lock" metaphor in molecular biology, see Friedrich Cramer, 'Emil Fischers Schlüssel-SchloßHypothese der Enzymwirkung - 100 Jahre danach', in Hans-Jörg Rheinberger, Michael Hagner and Bettina Wahrig-Schmidt (eds), Räume des Wissens.

Repräsentation, Codierung, Spur, Berlin, AkademieVerlag, 1997, pp. 191-212. The idea of cellular regeneration stemmed from Ehrlich's cousin Carl Weigert and was developed in contact with the latter, see Heymann, ibid. For the toxin-antitoxin
}

reaction and Ehrlich's work, see Pauline $\mathbf{M ~ H}$ Mazumdar, 'The antigen-antibody reaction and the physics and chemistry of life', Bull. Hist. Med., 1974, 48: 1-21.

${ }^{66}$ For this period of Ehrlich's work, see Dolman, op. cit., note 16 above, p. 298.

${ }^{67}$ For the work done in the Institut für Serumforschung und Serumprüfung in Steglitz, see Wilhelm Dönitz, 'Bericht über die Thätigkeit des Königl. Instituts für Serumforschung und Serumprüfung zu Steglitz, Juni 1896-

September 1899', Klin. Jahrb., 1899, 7: 359-84. Dönitz remarked that the biological application of the chemical theory of the side-chains would be the basic idea of all research acitivities of the Institute. 


\section{Cay-Rüdiger Prüll}

latter was set up for Ehrlich by the Prussian State, again with the support of Althoff. ${ }^{68}$ Ehrlich was able to organize and to co-ordinate experimental studies, and he pushed many assistants to work hard on their subjects. His right-hand man and coordinator for the laboratory investigations on the side-chain theory was the bacteriologist Julius Morgenroth (1871-1924), who had been Ehrlich's assistant in Steglitz since $1897 .^{69}$ But Ehrlich continued to be the spiritus rector of the whole project, and he urged his assistants to perform more and more animal experiments to consolidate his theory. Ehrlich's laboratory notes show this, as for instance when he demanded: "Please also show me the Pyrodinanimals", or simply "Where is the ape?"70 Accordingly, the "side-chain theory" developed. The "toxoids", those poisons capable of cell-binding, were supplemented by the "toxons" (Toxone) only a year later, in $1898 .{ }^{71}$ The toxons were also ineffective poisons, but, in contrast to the toxoids, they were synthesized and released by the microbe itself and had not lost their toxophore group.

Besides analysing poisons, Ehrlich concentrated on the mechanisms and processes of the side-chain theory itself. The animal experiments on haemolysis, i.e. the solvent action of antibodies on red blood corpuscles, seemed to be helpful. This could be compared with antibodies attacking bacilli. Some studies on haemolysis, published together with Morgenroth, enabled Ehrlich to improve the side-chain theory decisively. The so-called "addiment" (Addiment), was responsible for the dissolution of the red blood cells through binding to an antibody or "immune-body" (Immunkörper), enabling this antibody to bind to red blood cells and to dissolve them. Consequently, Ehrlich assumed that there were not only antibodies with one binding group but also antibodies with two binding groups. These were able to bind the "addiment" as well as the red blood cell. Now Ehrlich compared haemolysis with the physiological process of nutrition. This increased the impact of his theory. The addiment could be compared with a digestive ferment. A double-binding sidechain attached to the surface of a cell could bind both a digestive ferment and "giant molecules" (Riesenmoleküle), i.e. unprepared nutritive substances. These giant molecules could be prepared for cellular digestion by the digestive ferment. ${ }^{72}$ In this way, Ehrlich opened up the path from the more or less narrow immunological terrain to the understanding of the general metabolism of the human organism.

The side-chain theory appeared to be a good explanatory model to uncover the deepest secrets of biological chemistry. In 1899, Ehrlich postulated a countless number of sidechains, which would adapt to the "constantly changing chemistry" of the body. This chemistry would be influenced by race, sex, nutrition, energy, secretion and other factors, and so there was a continuous change taking place in the blood serum. Furthermore, not only in the case of haemolysis but also in regular conditions, the blood contained immune bodies

\footnotetext{
${ }^{68}$ Goldsmith, op. cit., note 5 above, p. 78.

${ }^{69}$ For the life of Morgenroth, see Bäumler, op. cit., note 5 above, p. 329; Dönitz, op. cit., note 67 above, p. 360 .

70 "Bitte mir auch die pyrodin-thiere zeigen!", "Wo bleibt der Affe !", see Note, 6 March 1900, p.13; Note, 1900 (no day and month), p. 30, in Zettel Buch I, 1 Feb. 1900, to 26 Dec. 1900, box 7, series II, (3)-1, 2, 4, Paul Ehrlich Collection, RUA, RAC.
}

\footnotetext{
${ }^{71}$ Paul Ehrlich, 'Über die Constitution des Diththeriegiftes' (Deutsche Medizinische Wochenschrift, 1898), in Himmelweit (ed.), vol. 2, op. cit., note 4 above, pp. 126-33.

${ }^{72}$ Paul Ehrlich and Julius Morgenroth, 'Zur Theorie der Lysinwirkung' (Berliner Klinische Wochenschrift, 1899), in Himmelweit (ed.), vol. 2, op. cit., note 4 above, pp. 143-9. English transl. pp. $150-5$.
} 


\section{Paul Ehrlich and his Receptor Concept}

with two binding sites. Ehrlich called them "interbodies" (Zwischenkörper). Normal blood also contained addiment, which Ehrlich called "complement" (Komplement) ${ }^{73}$

Finally, in 1900, Ehrlich and his colleague Morgenroth, in their third paper on haemolysins, introduced the term "receptor": "For the sake of brevity, that combining group of the protoplasmic molecule to which the introduced group is anchored will hereafter be termed receptor." 74 The side-chains as such had played a minor role in Ehrlich's research until this point in his career. He had concentrated mainly on the relations between poison, addiment, ferment and complement, less on the character of the side-chain as such. The titles of the published papers illustrate this. Even the third paper on haemolysins is chiefly about the classification of the different kinds of complement. ${ }^{75}$ The fourth report on haemolysins also deals mainly with complement. Ehrlich and Morgenroth claimed that there were many types and the constitution of the complement became also more intricate. ${ }^{76}$

The introduction of the term "receptor" was not merely a new term for an "old idea". 77 After having sorted out the meaning of the "side-chains" with the creation of a "side-chain theory", investigation of the nature of side-chains was inevitable. The new heading stands for the central position of the side-chains in Ehrlich's new research strand. The "receptors" and their specificity for certain poisons soon stood in the centre of Ehrlich's immunological theory. ${ }^{78}$ In 1901, Ehrlich and Morgenroth, when deepening their research on the general topic, made some remarks on the "peculiarities of the receptor apparatus". They stated that there would be a vast number of receptors attached to the red blood cells and that these receptors could bind to diverse immune bodies and haemotoxins. ${ }^{79}$ As in the case of the antibodies or intermediate bodies, the structure of the receptors was analysed and classified. As complex receptors with two haptophore groups, the intermediate bodies (antibodies regularly belonging to the immune system) were now called "amboceptors" (Amboceptoren) ${ }^{80}$ This view of receptors saw them as flexible entities, first of all attached to the cell and binding toxins or immune bodies, but then also doing the same in the blood-stream. ${ }^{81}$ But Ehrlich conceded soon that there were receptors which, even in the case of a successive

73 “... ständig wechselnden Chemismus", see Paul Ehrlich and Julius Morgenroth, 'Über Hämolysine. Zweite Mittheilung' (Berliner Klinische Wochenschrift, 1899), in Himmelweit (ed.), vol. 2, op. cit., note 4 above, pp. 156-64, esp. p. 162. English transl. pp. 165-72, esp. p. 170.

74 "Wir wollen im Folgenden stets, um eine grössere Kürze des Ausdrucks zu ermöglichen, diejenige bindende Gruppe im Protoplasmamolekül, an welche eine fremde, neu eingeführte Gruppe angreift, allgemein als 'Receptor' bezeichnen". See Paul Ehrlich and Julius Morgenroth, 'Über Hämolysine. Dritte Mittheilung' (Berliner Klinische Wochenschrift, 1900), in Himmelweit (ed.), vol. 2., op. cit., note 4 above, pp. 196-204, esp. p. 196. English transl. pp. 205-12, the quotation is on p. 205.

${ }^{75}$ Ibid.

${ }^{76}$ Paul Ehrlich and Julius Morgenroth, 'Über Hämolysine. Vierte Mittheilung' (Berliner Klinische Wochenschrift, 1900), in Himmelweit (ed.), vol. 2, op. cit., note 4 above, pp. 213-23. English transl. pp. 224-33.
${ }^{77}$ See the quotation in Silverstein, op. cit., note 2 above, p. 80. The introduction of the term "receptor" in 1900 is underestimated by Silverstein, who describes it merely as a "reminder that the side-chain theory holds that antibodies are cell receptors", p. 105.

${ }^{78}$ E Freiherr von Dungern, 'Rezeptorenspezifität', in Apolant, et al., op. cit., note 19 above, pp. 162-5.

79 "Eigenthümlichkeiten des Receptorenapparates", see Paul Ehrlich and Julius Morgenroth, 'Über Hämolysine. Fünfte Mittheilung' (Berliner Klinische Wochenschrift, 1901), in Himmelweit (ed.), vol. 2, op. cit., note 4 above, pp. 234-45, esp. p. 238. English transl. pp. 246-55, esp. p. 249.

${ }^{80}$ Ibid., p. 244, German original. Paul Ehrlich and Julius Morgenroth, 'Über Hämolysine. Sechste Mittheilung' (Berliner Klinische Wochenschrift, 1901), in Himmelweit (ed.), vol. 2, op. cit., note 4 above, pp. 256-77, esp. p. 272. English transl. pp. 278-97.

${ }^{81}$ Lazarus, op. cit., note 47 above, pp. 41-2. 


\section{Cay-Rüdiger Prüll}

overproduction of the cell, would not be released into the blood-stream. Instead they remained at the surface of the cell. Ehrlich called them "sessile receptors" (sessile Receptoren). ${ }^{82}$ But they remained as only one subspecies. Some receptors were common to different animal species and could be found in many organs. A receptor could have many complement binding groups, so mutating to a "triceptor" (Triceptor) or "quadriceptor" (Quadriceptor) ${ }^{83}$ The step to postulate the existence of the "polyceptor" (Polyceptor), able to bind many complements, was eventually taken in $1905 .{ }^{84}$ One year before, in 1904, Ehrlich had divided the receptors according to their ability to bind substances, distinguishing receptors of first, second and third order. ${ }^{85}$ All those with two or more binding sites belonged to the receptors of third order. The blood plasma was filled with a vast number of receptors, which Ehrlich called "haptines" (Haptine). These haptines covered all those substances which at the time were not yet identified. ${ }^{86}$ Finally, he approached what he called the "pluralistic point of view" (plurimistischer Standpunkt). This was the assumption of a whole range of different complements, anti-complements, receptors, and many other substances. ${ }^{87}$ Because they played a key role in immunology and in combating microbes, ${ }^{88}$ as well as in the physiology of nutrition and human metabolism in general, Ehrlich predicted a great impact of the receptor concept on clinical medicine, and he assumed that his studies on receptors would "open a new meaningful direction of biological research". 89

\section{(5) The Fight for the Receptors and Lost Alternatives}

Ehrlich's experimental methods were refined again and again, for example with the application of new chemicals. He got confirmation and support from colleagues, but he could not provide direct evidence for his theory as the receptors were not visible. ${ }^{90}$ The experimental setting and his exact methods enabled Ehrlich to identify the microcosmos of substances only indirectly, from reactions of the blood sera. He knew that his theory for the present remained only a theory. But because it was based on experimental evidence, he thought it legitimate to publish the results. ${ }^{91}$ In 1901 , he maintained that the side-chain

\footnotetext{
${ }^{82}$ Ehrlich and Morgenroth, 'Über Hämolysine. Sechste Mittheilung', op. cit., note 80 above, pp. 256, 258.

${ }^{83}$ Ibid., pp. 268, 273.

${ }^{84}$ Paul Ehrlich and Hans Sachs, 'Über den Mechanismus der Antiamboceptorwirkung' (Berliner Klinische Wochenschrift, 1905), in Himmelweit (ed.), vol. 2, op. cit., note 4 above, pp. 432-41, esp. p. 434.

${ }^{85}$ Paul Ehrlich, 'Über den Receptorenapparat der rothen Blutkörperchen', from Paul Ehrlich (ed.),

Gesammelte Arbeiten zur Immunitätsforschung, Berlin, Hirschwald, 1904, in Himmelweit (ed.), vol. 2, op. cit., note 4 above, p. 316-23, esp. p. 317.

${ }^{86}$ Paul Ehrlich, 'Die Schutzstoffe des Blutes' (Verhandlungen der 73. Versammlung der Gesellschaft der Naturforscher und Ärzte, 1901), in Himmelweit (ed.), vol. 2, op. cit., note 4 above, p. 298-315, esp. p. 312 .

${ }^{87}$ Ibid., p. 313.
}

\footnotetext{
${ }^{88}$ Ehrlich decided to apply a specific bacterial serum to different animal species with a different receptor apparatus. Thus he aimed to produce antibodies against all bacterial receptors of this microbe. $\mathrm{He}$ thought this a possible way of mapping all receptors of this microbe. It could then be combatted effectively with a therapeutic serum produced from the mixture of the produced antibodies. See Ehrlich and Morgenroth, 'Über Hämolysine. Sechste Mittheilung', op. cit., note 80 above, p. 259.

89 “... eine neue bedeutungsvolle Richtung der biologischen Forschung eröffnet". See Ehrlich, op. cit., note 85 above, p. 320 . See also Dolman, op. cit., note 16 above, pp. 298-9.

${ }_{90}$ Dönitz, op. cit., note 67 above, pp. 376-84.

${ }^{91}$ Paul Ehrlich, 'Toxin und Antitoxin. Entgegnung auf den neuesten Angriff Grubers' (Münchener Medizinische Wochenschrift, 1903), in Himmelweit
} 


\section{Paul Ehrlich and his Receptor Concept}

theory had "passed the test perfectly". 92 The appearance of scientific phenomena that were inconsistent with his theory were explained by Ehrlich as a result of the highly intricate conditions of the animal organism. The inconsistencies would serve to deepen the theory and to promote its success. ${ }^{93}$ Thus a theory should not be dismissed as soon as any contradiction occurred, but should be carefully rethought. Ehrlich saw himself as a pioneer of a new medicine of the future, and he compared his "side-chain theory" with Rudolf Virchow's (1821-1902) "cellular pathology", which also had not been successful at once. ${ }^{94}$

The insecure basis of Ehrlich's theory provoked critics even at an early stage in its development. The critics and his way of dealing with them led Ehrlich deeper into his receptor concept. He attributed what he called the "unitarian view" (unitarischer Standpunkt) to many of his critics. This attitude stood in sharp contrast to his own "pluralistic conception" ( plurimistische Anschauung). Based on their own experiments, the unitarians attacked specific points of the side-chain theory and thereby questioned Ehrlich's microcosmos of immunological substances. ${ }^{95}$ Ehrlich identified one opposing group of scientists at the Pasteur Institute in Paris: the French immunologist and bacteriologist Emile Roux (1853-1933), made deputy director in 1895 and since 1904 director of the Pasteur Institute, his Belgian colleague and co-worker Jules Bordet (1870-1961), and the Russian immunologist and bacteriologist Elie Metchnikoff (1845-1916), who had worked at the Institute since 1888. The dispute between these three researchers on one side and Ehrlich

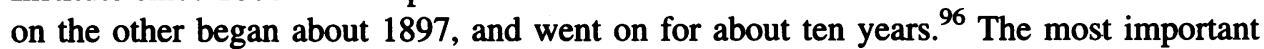
conflict was, however, with Jules Bordet. The latter had developed a special theory on the dissolution of red blood cells. In 1900, Bordet declared there to be no direct relation between immune bodies and complement. The red blood cells were merely made sensitive by the immune bodies - a view rejected by Ehrlich as purely mechanistic. Following that, the cells were influenced by the complement, which Bordet named "alexine" (Alexin). Furthermore, Bordet questioned the existence of a variety of immune bodies on the basis of his own experiments on haemolysis. In one species there was only one alexine, causing both haemolysis and bacteriolysis. ${ }^{97}$

Such attacks annoyed Ehrlich considerably, and the example of the Paris trio reveals his methods of dealing with critics of the side-chain theory. Ehrlich instructed his assistants to

(ed.), vol. 2, op. cit., note 4 above, pp. 368-90, esp. p. 383.

92 "... die Probe des Versuchs aufs Beste bestanden". See Ehrlich, op. cit., note 86 above, p. 306.

${ }^{93}$ Ehrlich and Morgenroth, 'Über Hämolysine. Fünfte Mittheilung', op. cit., note 79 above, pp. 234-5.

${ }^{94}$ Paul Ehrlich to Veit (this could have been either Gustav Veit or Johann Veit), 22 Jan. 1903, in Direktor, Ehrlich X, 23 Dec. 1902 to 26 Jan. 1903, box 22, series V, (3-complete)-1, 2, 4 (2-incomplete), pp. 169-71, esp. 171, Paul Ehrlich Collection, RUA, RAC.

${ }_{95}$ Ehrlich and Morgenroth, 'Über Hämolysine. Sechste Mittheilung', op. cit., note 80 above, pp. 256-7, English transl. pp. 278-9.

${ }_{96}$ See Ehrlich's remark about Roux and Büchner which seems to have started the dispute about the sidechain theory, Paul Ehrlich, 'Zur Kenntnis der

Antitoxinwirkung' (Fortschritte der Medizin, 1897), in
Himmelweit (ed.), vol. 2, op. cit., note 4 above, pp. 84-5.

${ }^{97}$ Ehrlich and Morgenroth, 'Über Hämolysine. Vierte Mittheilung', op. cit., note 76 above, pp. 214, 218, 220-3. For Bordet, see Jules Bordet, 'Le

Mécanism de l'agglutination', Annales de L'Institut Pasteur, 1899, 13: 225-50; idem, 'Agglutination et dissolution des globules rouges par le sérum', Annales de L'Institut Pasteur, 1899, 13: 273-97; idem, 'Les sérums hémolytiques, leurs antitoxines et les théories des sérums cytolytiques', Annales de L'Institut

Pasteur, 1900, 14: 257-96. See also Aschoff, op. cit., note 9 above, pp. 96-8; Silverstein, op. cit., note 9 above, pp. 99-104, and the detailed analysis of Eileen Crist and Alfred I Tauber, 'Debating humoral immunity and epistemology: the rivalry of the immunochemists Jules Bordet and Paul Ehrlich', J. Hist. Biol., 1997, 30: 321-56, esp. p. 329. 


\section{Cay-Rüdiger Prüll}

repeat Bordet's experiments, and under the heading "against Bordet" (gegen Bordet) he gave directions on pieces of paper. The results of the experiments did not lead to a revision of the side-chain theory, but to its vindication. The newly obtained immunological knowledge was integrated into Ehrlich's flexible, pluralistic theory. ${ }^{98}$ In this sense all the contributions of Ehrlich and his workers served not only to consolidate the side-chain theory but also to defend it against any objections. Ehrlich had a busy correspondence with colleagues. In his letters, he reported promptly on his latest findings and dissected the experiments of his opponents, describing them as failed criticism of the side-chain theory. For example, Ehrlich reported to a colleague that Metchnikoff was the "real spiritus rector" of the attacks from Paris, having softsoaped Roux with his "breathtaking personality". It was "such a shame that such an experimenter and such a clear head as Roux got so deeply into mysticism and into the Russian fog". ${ }^{99}$ Ehrlich was friends with many of his opponents, but when it came to his theory, he unfolded a massive campaign against any critics, in front or behind the curtain. Ehrlich complained about seemingly disparaging remarks in secondary literature. Once he tried to urge the editor of the journal Deutsche Medizinische Wochenschrift to stop the printing of critical remarks by one of his opponents, because his own theory "had gained full acceptance already". ${ }^{100}$ Ehrlich sorted his colleagues into friends and enemies of his theory. In October 1902, he wrote to William Henry Welch (1850-1934): "I was most delighted to recognize you as one of the warmest friends of the theory, but even more that you could achieve such new and fundamental insights with its help". In contrast, he wrote to a pharmacologist in Halle, Germany, "that every impartial person reading the literature has to count you as an absolute opponent". ${ }^{101}$ Again, Ehrlich related the remark to "the theory", which occupied him more and more in the years after 1897. This becomes apparent through other critics of his concept.

\footnotetext{
${ }^{98}$ Two Laborzettel, both 1901, in Zettel Buch II und Carcinom, 25 Dec. 1900 to 21 Sept. 1901, box 8, series II, (3)-1, 2, 4, pp. 292, 293, Paul Ehrlich Collection, RUA, RAC. For some general remarks on the dispute between Ehrlich and Bordet, see also Arthur M Silverstein, 'Pasteur, Pastorians, and the dawn of immunology: the importance of specificity', Hist. Philos. Life Sci., 2000, 22: 29-41, esp. pp. 37-9; and the comments of August von Wassermann, op. cit., note 19 above, pp. 148-50.

99 “... der 'wirkliche spiritus rector'; mit seiner 'hinreissenden persönlichkeit'. Es sei 'jammerschade, dass ein solcher experimentator und klarer kopf wie Roux so in den mysticismus und den russischen nebel gerathen musste!'”. See Paul Ehrlich to Carl Salomonsen, Copenhagen, 24 Feb. 1899, in Copir Buch III. Ehrlich, 21 Feb. 1899 to 31 July 1899, box 5, series I, (3)-1, 2, 4, pp. 13-16, Paul Ehrlich Collection, RUA, RAC. Metchnikoff's theory of phagocytosis (digestion) of bacilli through leucocytes and the latter's ability to produce antitoxin was seen as an attack on the "sidechain theory" by Ehrlich; see Aschoff, op. cit., note 9 above, pp. 28, 42-3, 103-4, 115-17. For some general remarks on the dispute between Ehrlich and Metchnikoff, see Silverstein, op. cit., note 98 above, pp.
}

35-7; Oswin Günther, 'Immunitätstheorien. Von der Seitenkettentheorie zur Fließbandtheorie', in Zum 100. Geburtstage Paul Ehrlichs und zum Wiederaufbau des Paul-Ehrlich-Instituts, Arbeiten aus dem Paul-EhrlichInstitut, dem Georg-Speyer-Haus und dem FerdinandBlum-Institut zu Frankfurt a. M., Issue 51, Stuttgart, Gustav Fischer, 1954, pp. 68-107, esp. pp. 75-81. 100 “. . . in der ganzen Linie sich anerkennung verschafft haben". See Paul Ehrlich to Rudolf Kobert, Rostock, 1 Dec. 1902; Paul Ehrlich to Albert Eulenburg, Berlin, 15 Nov. 1902, in Direktor, Ehrlich IX, 25 Sept. 1902 to 23 Dec. 1902, box 21, series V, (3-complete)-1, 2, 4 (2-incomplete), pp. 434-47, esp. 434-7; pp. 376-7, quotation on p. 377, Paul Ehrlich Collection, RUA, RAC.

101 "Hocherfreulich war es mir, Sie wieder als einen so warmen freund der theorie zu erkennen, noch mehr aber, dass Sie durch diesselbe zu so neuen und fundamentalen gesichtspunkten gekommen sind"; "dass jeder Unbefangene, der die Literatur liest, Sie zu den absoluten Gegnern zählen muss."; See Paul Ehrlich to William H Welch, Baltimore, 20 Oct. 1902; Paul Ehrlich to Ernst Fuld, Halle, 27 Oct. 1902, in Direktor, Ehrlich IX, ibid., pp. 117-18, 182-7, esp. pp. 182-3. 


\section{Paul Ehrlich and his Receptor Concept}

Ehrlich's style of dealing with critics of the side-chain theory can also be found in his controversy with the physical chemist Svante Arrhenius (1859-1927) and his student Thorvald Madsen (1870-1957), which started in 1903. Ehrlich had to defend his biological point of view against a physico-chemical interpretation of antitoxin-toxin binding. Arrhenius and Madsen applied basic chemical laws to processes of life, which, according to Ehrlich, could not be expressed in such rigid formulas. Above all, Arrhenius adopted Bordet's unitarian point of view on the complement and the haemolysis of blood ${ }^{102}$ Ehrlich again carried out experiments and started a letter campaign against Arrhenius. ${ }^{103}$ In a letter to Althoff, presumably written in 1904, Ehrlich noted that Arrhenius would be "pushed to the wall". 104

Even more serious was Ehrlich's dispute with Max von Gruber (1853-1927), professor of hygiene at Vienna from 1887 to 1902 and at Munich from 1902 to 1923 . Although giving him credit for new findings in the field of immunology, Gruber attacked Ehrlich's pluralism of specific toxines and immune bodies in a very polemical way, as purely speculative with a nearly total lack of evidence. He did this in several papers on immunology, published between 1901 and 1903. Again, Ehrlich made tremendous efforts to explain to his academic friends the weakness of Gruber's criticism. Ehrlich and some colleagues were even evicted from a train, because the former had complained loudly about the rhetoric of Gruber. ${ }^{105}$ Ehrlich rejected the hygienists' criticism entirely as "stupid" (blödsinnig) and treated it as a "quantité négligeable". This again led Gruber to point out "that he solely reproaches him [Ehrlich] for in the course of his theorizing permitting too much fantasy and too little criticism". 106 Beyond any judgement on the comments of the "gifted polemicist"

${ }^{102}$ Paul Ehrlich to Svante Arrhenius, 1 Jan. 1903, in Direktor, Ehrlich X, 1902, 23 Dec. to 26 Jan. 1903, box 22, series V, (3-complete)-1, 2, 4 (2-incomplete), pp. 71-9, Paul Ehrlich Collection, RUA, RAC. Svante Arrhenius and Thorvald Madsen, 'Anwendung der physikalischen Chemie auf das Studium der Toxine und Antitoxine', Zeitschrift für Physikalische Chemie, 1903, 44: 7-62; Svante Arrhenius, Quantitative laws in biological chemistry, London, G Bell, 1915, esp. pp. 110-39. For a detailed description of the EhrlichArrhenius controversy, see Lewis P Rubin, 'Styles in scientific explanation: Paul Ehrlich and Svante Arrhenius on immunochemistry', J. Hist. Med. Allied Sci., 1980, 35: 397-425.

${ }^{103}$ For example, Paul Ehrlich to Paul Heinrich Römer, 8 July 1903, in Direktor, Ehrlich XI, 1903, 13 Mar. to 17 July 1903, box 23, series V, pp. 445-8; Paul Ehrlich to S J Meltzer, 30 Dec. 1903, in Direktor, Ehrlich XIII, 21 Dec. 1903 to 13 June 1904, box 23, series V, pp. 44-6, Paul Ehrlich Collection, RUA, RAC. See also further letters of Ehrlich in this file.

${ }^{104}$ Paul Ehrlich to Friedrich Althoff, 12 Sept. presumably 1904, in Nachlass Althoff A I, GStA PK. VI. HA, Rep. 92, No. 258, pp.15-16, esp. pp. 22-30. For the controversy between Ehrlich and Arrhenius/ Madsen, see also Pauline M H Mazumdar, Species and specificity: an interpretation of the history of immunology, Cambridge University Press, 1995, pp. 202-13.
${ }^{105}$ Claude E Dolman, 'Paul Ehrlich and William Bulloch: a correspondence and friendship (18961914)', Clio Medica, 1968, 3: 65-84, esp. pp. 80-1; Max Gruber, 'Zur Theorie der Antikörper. I. Ueber die Antitoxin-Immunität', Münchener Medizinische Wochenschrift, 1901, 48: 1827-30, 1880-4; idem, 'Zur Theorie der Antikörper. II. Ueber Bakteriolyse und Haemolyse', ibid., pp. 1924-7, 1965-8; idem, Cl. Freiherr v. Pirquet (Referent: M. Gruber), 'Toxin und Antitoxin', Münchener Medizinische Wochenschrift, 1903, 50: 1193-6, esp. p. 1194; Max Gruber, 'Toxin und Antitoxin. Bemerkungen zu Ehrlichs "Entgegnung auf Grubers Replik"', Münchener Medizinische Wochenschrift, 1903, 50: 2297; idem, 'Neue Früchte der Ehrlichschen Toxinlehre', Wiener Klinische Wochenschrift, 1903, 16: 791-3.

${ }^{106}$ Paul Ehrlich to Paul Heinrich Römer, 8 July 1903, in Direktor, Ehrlich XI, 13 Mar. 1903 to 17 July 1903, box 23, series V, pp. 445-8, Paul Ehrlich Collection, RUA, RAC: “... ich mache ihm nur zum Vorwurf, dass er bei seinem Theoretisieren zuviel Phantasie und zu wenig Kritik walten lasse". See Max Gruber, 'Toxin und Antitoxin. Eine Replik auf Herrn Ehrlichs Entgegnung', Münchener Medizinische Wochenschrift, 1903, 50: 1825-8, esp. p. 1825. 


\section{Cay-Rüdiger Prüll}

Gruber, ${ }^{107}$ it is evident that he hit Ehrlich on a vulnerable spot. All the inventions of new terms and substances could not really explain the formation of antibodies. Gruber made one general remark which explains his attitude best: "Only the conditions which accompany the processes of life are accessible to our research". ${ }^{108}$ Ehrlich, despite his adverse reaction to Gruber's remarks, published two papers devoted to his opponent in $1903 .^{109}$

The strongest blow against Ehrlich's side-chain and receptor theory came from a group of immunochemists, who attacked the chemical specificity of the concept on unitarian grounds. The most important of these was the Viennese pathologist and immunologist Karl Landsteiner (1868-1943). As a student of Gruber in 1896, he became involved in the dispute with Ehrlich and joined the front-line of Ehrlich's opponents. Landsteiner then developed the colloid theory of immunology: reactions are influenced by the chemical constitution of substances, but above all the quantitative relationship is influenced by physical phenomena such as solubility and temperature. Echoing Gruber's criticism, Landsteiner attacked Ehrlich's "uneconomical" pluralism, which in his view was loaded with too many uncertainties. From 1903 onwards, Landsteiner invaded the field of immunology with his theory. ${ }^{110}$ By 1912 "the colloid theory had superseded Ehrlich's, although in the practice of the serum institutes the old assumption of clear-cut, one-to-one specificity was essentially unchanged". 111

All these critics did not lead Ehrlich to rethink his pluralistic attitudes. On the contrary, as many printed and unprinted sources show, he became more and more obsessed with his theory in the first years after 1900. Ehrlich always had only a meagre interest in culture and politics, and there are no hints that he recognized his involvement in the state-oriented and nationalistic bacteriological research of his teacher Koch. ${ }^{112}$ Ehrlich talked incessantly about his work, painted sketches of the receptors on note-pads, letters, postcards and even on the floor or tablecloths. ${ }^{113}$ And, as we know from the recent contribution of Cambrosio, Jacobi and Keating, the images themselves fuelled the criticism of their opponents that they were an attempt by Ehrlich to illustrate invisible structures, whose material existence was not evident but debated at this time. Bordet made Ehrlich's graphic representations responsible for the success of the side-chain theory, arguing that it was not based on fact but on

\footnotetext{
${ }^{107}$ Michael Hubenstorf described Gruber as a "gifted polemicist" (begabter Polemiker), see idem, 'Gruber, Max (von)', in Wolfgang U Eckart and Christoph Gradmann (eds), Arzte Lexikon. Von der Antike bis zur Gegenwart, 2nd ed., Berlin and Heidelberg, Springer, 2001, pp. 140-1, esp. 140.

108 "Nur die begleitenden Umstände der Lebensvorgänge sind unserer Forschung zugänglich." See Gruber, op. cit., note 106 above, p. 1827.

${ }^{109}$ Ehrlich, op. cit., note 91 above; idem, 'Toxin und Antitoxin. Entgegnungen auf Grubers Replik' (Münchener Medizinische Wochenschrift, 1903), in Himmelweit (ed.), vol. 2, op. cit., note 4 above, pp. 39194. For the debate with Gruber, see Silverstein, op. cit., note 9 above, pp.104-7. For the controversy between Ehrlich and Gruber, see Mazumdar, op. cit., note 104 above, pp. 123-35.

${ }^{110}$ See the detailed analysis in Mazumdar, op. cit., note 104 above, pp. 107-278, esp. pp. 136, 216-17, 147, 226.
}

\footnotetext{
${ }^{111}$ Ibid., p. 255.

${ }^{112}$ See Paul Weindling, 'Scientific elites and laboratory organisation in fin de siècle Paris and Berlin: the Pasteur Institute and Robert Koch's Institue for Infectious Diseases compared', in Andrew Cunningham and Perry Williams (eds), The laboratory revolution in medicine, Cambridge University Press, 1992, pp. 170-88; Christoph Gradmann, 'Money and microbes: Robert Koch, tuberculin and the foundation of the Institute for Infectious Diseases in Berlin in 1891', Hist. Philos. Life Sci., 2000, 22: 59-79; HeinzPeter Schmiedebach, 'The Prussian state and microbiological research-Friedrich Loeffler and his approach to the "invisible" virus', Arch. Virol., 1999, 15: Suppl., pp. 9-23; Ragnhild Münch and Stefan S Biel, 'Expedition, Experiment und Expertise im Spiegel des Nachlasses von Robert Koch', Sudhoffs Archiv, 1998, 82: 1-29.

${ }_{113}$ Marquardt, op. cit., note 17 above, pp. 29, 36, 40-2, 54-5.
} 


\section{Paul Ehrlich and his Receptor Concept}

image, which was then wrongly accepted as the picture of real material life. ${ }^{114}$ Remarkably enough, Ehrlich's efforts to consolidate the receptor theory were supported by the realm of literary fiction. One of the few things Ehrlich did in his leisure hours was to read detective stories, especially those of Sir Arthur Conan Doyle (1859-1930). These served to stimulate reflection on his work, for he filled the margins with comments and formulas. ${ }^{115}$ The ideas of his teacher Robert Koch flooded back in his mind through literature: Conan Doyle was an admirer of Koch and did not hesitate to travel to Berlin in 1890 to investigate the bacteriologist's tuberculin cure. Doyle's fascination with the idea of preventing the invasion of the empire by microbes shaped the work of his fictional hero Sherlock Holmes. The latter concentrated explicitly on detecting the "invisible" and subversive threads of life. Doyle saw both Holmes and Koch as "imperial knights" who saved their empires. 116

The experimental facts and the production of sketches of the actually invisible immunological entities conflated in Ehrlich's work. ${ }^{117}$ Together both had to ensure the credibility of the side-chain and receptor theory just as visual (early photography) and functional (animal experimentation) proof had to demonstrate evidence for Koch's postulation of living microbes. ${ }^{118}$ Ehrlich explained that his sketches would be "merely a pictorial method" and therefore that they did not correspond to reality. ${ }^{119}$ But such singular remarks fade before the extensive use Ehrlich made of his pictures to persuade his contemporaries of the truthfulness of his theory. The images, as well as their conflation with experimental evidence, were in turn boosted by the criticism of them. The system allowed Ehrlich to reconstruct and enlarge his receptor concept infinitely as there was no factual resistance. Therefore, notwithstanding the opposing views, Ehrlich compared himself with a victorious chess player who cannot finish the game because his defeated opponents do not want to give up. ${ }^{120}$ The intense concentration on the side-chains and the receptors decreased only gradually until 1905, in parallel with the increase of his cancer research and finallyfrom about 1906 - with his work on chemotherapy. The impact of Landsteiner's immunological theory on Ehrlich's shift of interests is questionable: in 1906, Ehrlich was still criticizing colloid chemistry. ${ }^{121} \mathrm{He}$ thought his own theory complete and he now used it as a tool to examine other fields of medical research. ${ }^{122}$

\footnotetext{
${ }^{114}$ Alberto Cambrosio, Daniel Jacobi, and Peter Keating, 'Ehrlich's "beautiful pictures" and the controversial beginnings of immunological imagery', Isis, 1993, 84: 662-99, esp. pp. 667-9, 684; Crist and Tauber, op. cit., note 97 above, pp. 336-7; 346-53.

${ }^{115}$ Marquardt, op. cit., note 17 above, pp. 28-9; Dolman, op. cit., note 105 above, p. 81 .

${ }^{116}$ For Doyle's work and its interpretation see the brilliant analysis of Laura Otis, 'Arthur Conan Doyle: an imperial immune system', in idem, Membranes: metaphors of invasion in nineteenth-century literature science, and politics, Baltimore and London, Johns Hopkins University Press, (1999) 2000, pp. 90-118, esp. pp. 91-8.

${ }^{117}$ Cambrosio, Jacobi, and Keating, op. cit., note 114 above, p. 699.

${ }^{118}$ Thomas Schlich, 'Linking cause and disease in the laboratory: Robert Koch's method of superimposing visual and "Functional" representations
}

of bacteria', Hist. Philos. Life Sci., 2000, 22: 43-58.

${ }^{119}$ Paul Ehrlich, 'On immunity with special reference to cell life: Croonian Lecture (Proc. Roy. Soc. 1900), in Himmelweit (ed.), vol. 2, op. cit., note 4 above, pp. 178-95, here p. 187.

${ }^{120}$ Paul Ehrlich to Friedrich Althoff, Aug. 1903, in Nachlass Althoff B, GstA PK. VI. HA, Rep. 92, No. 33, pp. 142-3, esp. p. 142.

${ }^{121}$ Crist and Tauber, op. cit., note 97 above, p. 333. Crist and Tauber also point out that Ehrlich never abandonded his side-chain theory; see ibid., p. 325.

${ }^{122}$ For Ehrlich's extremely sensitive reaction to critics, see also the more or less hagiographic account of Walter Greiling, Im Banne der Medizin. Paul Ehrlich. Leben und Werk, Düsseldorf, Econ, 1954, pp. 120-2. Research on chemotherapy was above all carried out in the Georg-Speyer House, newly erected in 1906 . This Institute was attached to Ehrlich's Institute. See 


\section{Cay-Rüdiger Prüll}

Although he was very enthusiastic about the receptors, there are indications in Ehrlich's correspondence that he was not entirely satisfied with his situation. Even in the last Berlin years at the Institute in Steglitz, namely after 1898, Ehrlich was faced with the problem that as head of a theoretical institute he had no patients. ${ }^{123}$ The reason for his wish to have patients was the often repeated intention that "after having worked entirely on questions of serum therapy for such a long time, I want to turn a bit to my old pet subject again, which is histological and biological staining"; or, expressed in another way: "After the long period of immunological magic I am now again getting around to focus again a little bit on the dyes as my old pet subject ...". ${ }^{124}$ Although predominantly publishing on side-chains between 1897 and 1905 (twenty-eight papers), he did not stop publishing on dye-stuffs and their clinical application (six papers) as well as on purely chemical problems (two papers). ${ }^{125}$ Even in his immunological studies he did not hesitate to draw parallels with staining processes. Ehrlich was not very keen to work as a physician again, but rather to carry out the clinical testing of potential drugs. In the following period, he pre-tested dyes on animals, examined the side effects and thereafter sent them to clinicians with the request that they perform therapeutic human experiments. Ehrlich ordered the dye stuffs from pharmaceutical companies. Then he arranged for them to be packed into capsules before handing them over to physicians. This was meant to simplify the application to patients. ${ }^{126}$ The bottleneck in this system were the patients, and in the following years Ehrlich constantly begged clinicians to perform therapeutic experiments. The problem forced him to go back to those he knew well, for example his old friend Albert Neisser (1855-1916), a dermatologist in Breslau. In 1898 Ehrlich wanted Neisser to administer some of his dyes to patients. These dyes had already been tested on rabbits and hares, and had been well-tolerated. Ehrlich recommended a slow increase in the dosage, "first of all in cases of headaches, vague rheumatic plagues, gonorrhoea and cystitis". ${ }^{127}$ Neisser was willing to test the dye "brilliant blue" on patients. In November 1898, Ehrlich became pushy and urged Neisser to speed up the trials: "After all, however, it is not so difficult-considering your great experience with these things-to find the approximate dosage bene tolerata". ${ }^{128}$ Neisser, who was then involved in a scandal about his performance of human experiments on

'Das Speyer-Haus in Frankfurt a.M.' (Berliner Klinische Wochenschrift, 1906), in Nachlass Althoff A I, GStA PK. VI. HA, Rep. 92, No. 258, p. 66.

${ }^{123}$ Liebenau comments that the Institute in Frankfurt gave Ehrlich the opportunity to conduct "controlled bedside trials". Besides the problem of using modern terms and methods anachronistically; it should be remembered that Ehrlich was no longer attached to a clinical unit and that he relied on clinical colleagues to perform therapeutic human experimentation. See Liebenau, op. cit., note 46 above, p. 70. 124 “... nachdem ich so lange serumtherapeutische fragen fast ausschliesslich bearbeitet habe, mich wieder etwas mehr meinem alten lieblingsgebiet theorie der histologischen und biologischen färbung zuzuwenden."; "Nach dem langen immunitäts zauber komme ich jetzt wieder dazu, mich meinem alten lieblingsgebiet der farbstoffe wieder etwas zuzuwenden ...". See Paul Ehrlich to the Badische
Anilin- und Sodafabrik, Ludwigshafen, Nov. 15, 1898; Paul Ehrlich to Nietzki, 24 Dec. 1898, in Copir Buch II. Direktor, 11 Nov. 1898 to 21 Feb. 1899, box 4, series I, (3)-1, 2, 4, pp. 69, 242, Paul Ehrlich Collection, RUA, RAC.

${ }^{125}$ See Himmelweit (ed.), vols. 1-3, op. cit., note 4 above.

${ }^{126}$ See especially Ehrlich's letters in Copir

Buch II. Direktor, 11 Nov. 1898 to 21 Feb. 1899 , box 4, series I, (3)-1, 2, 4, Paul Ehrlich Collection, RUA, RAC.

127 “... zunächst bei kopfschmerzen, vagen rheumatoiden seuchen, gonorrhoe und cystitis." See Paul Ehrlich to Albert Neisser, no date, in ibid., pp. 93-4.

128 "Schliesslich ist es doch auch wohl nicht gar zu schwer-bei Eurer grossen übung in diesen dingen-die ungefähre dosis bene tolerata heraus $\mathrm{zu}$ bekommen". See Paul Ehrlich to Albert Neisser, 30 Nov. 1898 , in ibid., p. 128. 


\section{Paul Ehrlich and his Receptor Concept}

prostitutes and children without information and consent, tested several dyes for Ehrlich and discussed with him the patients chosen. ${ }^{129}$ Other colleagues were not as helpful as Neisser. Ehrlich repeatedly requested them to test his substances. Even if the clinician was in principle prepared to undertake the experiments, Ehrlich had to press forcefully for tests to be done and the results reported. The system did not work well and from June 1899 Ehrlich showed signs of frustration. He remarked to a colleague that "all these gentlemen undertake the staining therapy more or less to do me a favour but not out of deep conviction". 130

Finally, dye testing appears to have been a futile attempt to restore the old Charité conditions, where laboratory work and animal experimentation could be linked with clinical expertise. Ehrlich's favourite style of work was so well-known that in 1899 the administration of the city of Frankfurt feared that the patients of the city hospitals would be "used for experimental purposes". ${ }^{131}$ But what was left during his first years in Frankfurt were the merely theoretical studies on the receptors, based on animal trials and test tubes. Although basically satisfied with his independent position and his working conditions, ${ }^{132}$ Ehrlich also detailed the drawbacks when he described his work on the receptors in 1901: "Because I myself am not in a position to perform such investigations on a large number of patients, I thought it to be my duty to clarify my point of view and this way to lay the basis of the work in a field whose importance for pathology and therapy presumably will be fully acknowledged only after many years". ${ }^{133}$ In 1905 , this argument was essentially repeated when he explained that he had done his work and that "more new and successful work" could only be done by "specialists, who have the necessary clinical and pathological material". ${ }^{134}$ This did not mean that Ehrlich wanted to become a full clinician: in the same year, presumably because of responsibilities towards his Institute, he rejected the call

${ }^{129}$ Paul Ehrlich to Albert Neisser, 9 Dec. 1898; 7 Jan. 1899, in ibid., pp. 178, 179-80, esp. pp. 180, 299. See also Barbara Elkeles, 'Medizinische

Menschenversuche gegen Ende des 19. Jahrhunderts und der Fall Neisser: Rechtfertigung und Kritik einer wissenschaftlichen Methode', Medizinhist. J., 1985,

20: 135-48; idem, Der moralische Diskurs über das medizinische Menschenexperiment im 19. Jahrhundert, Stuttgart and New York, Fischer, 1996, esp. pp. 190-206.

130 “. ... alle diese herren treiben die farbentherapie eigentlich mehr aus gefälligkeit mir gegenüber, als aus innerer überzeugung." See Paul Ehrlich to Iwanoff, Petrowsk, 30 June 1899, in Copir Buch III. Ehrlich, 21 Feb. 1899 to 31 Jul. 1899, box 5, series I, (3)-1, 2, 4, pp. $398,399-402,403$, esp. pp. 398, 399, Paul Ehrlich Collection, RUA, RAC.

${ }^{131}$ Carl Weigert to Paul Ehrlich, 27 Mar. 1897, in Nachlass Althoff A I, GstA PK. VI. HA, Rep. 92, No. 258, pp. 15-16, esp. p. 15. In return for the contributions of the city of Frankfurt to the erection of Ehrlich's Institute, Ehrlich had to examine body fluids and organ specimens from patients of the city hospital. See Bäumler, op. cit., note 5 above, pp. 113-14; Paul
Ehrlich, 'Das Königliche Institut für experimentelle Therapie zu Frankfurt a.M.', Festschrift zum XIV. Internationalen Kongre $\beta$ für Hygiene und

Demographie, Berlin 1907, dargeboten von dem Preußischen Minister der geistlichen, Unterrichts- und Medizinalangelegenheiten, Jena, Fischer, 1907, in Nachlass Althoff B, GStA PK. VI. HA, Rep. 92, No. 33, pp. 244-55, esp. pp. 251-53. His cousin Carl Weigert persuaded Frankfurt's administration to agree to Ehrlich's and Althoff's plans.

${ }^{132}$ Paul Ehrlich to Friedrich Althoff, 23 Feb. 1900, in Nachlass Althoff B, GStA PK. VI. HA, Rep. 92, No. 33, pp. 114-15.

${ }_{133}$ "Da ich selbst nicht in der Lage bin, derartige Untersuchungen an einem grösseren Krankenmaterial durchzufuihren, habe ich es für meine Pflicht gehalten, die Gesichtspunkte klarzulegen und so die Basis für die Bearbeitung eines Gebietes zu schaffen, dessen Bedeutung für die Pathologie und Therapie vielleicht erst nach Jahren voll gewürdigt werden wird." See Ehrlich, op. cit., note 86 above, p. 315 .

${ }^{134}$ Paul Ehrlich to Friedrich Althoff, 1 Jan. 1905, in Nachlass Althoff B, GStA PK. VI. HA, Rep. 92, No. 33, pp. 150-6, on p. 153. 


\section{Cay-Rüdiger Prüll}

to become director of the First Medical Clinic in Vienna. ${ }^{135}$ But he wanted to be attached to clinical facilities as a laboratory worker. Ehrlich continued to be dependent on distant collaboration with physicians in respect of drug trials-for example with his teacher Koch. ${ }^{136}$ And finally it was partly due to the revival of the old idea of the therapeutic application of dyes, the application of trypan red to trypanosomes, that Ehrlich successfully developed Salvarsan. In combination with the old ideas, the theoretical work on the sidechains and receptors had its practical impact. ${ }^{137}$

\section{Paul Ehrlich, Pharmacology and the Receptors}

Contrary to the current perceptions of Ehrlich's research progression, there was a leitmotif, but no well developed master plan to lead him directly to the receptors. At the beginning of his Berlin period, under the clinician Friedrich Theodor Frerichs, Ehrlich advocated a concept which did not rely on the intricate construction of the side-chain theory as a predecessor of the receptor concept. Ehrlich's provisional ideas on the theoretical basis of his work did not play an important role in his objective of these years, namely to achieve practical therapeutic results. These could be achieved by combining his favourite, chemical laboratory work, with animal experimentation and therapeutic human experimentation in a pragmatic way, and there was no need to deepen knowledge of the side-chains. The end of Ehrlich's career in the clinical context, which was principally caused by the sudden death of Frerichs, should be considered more seriously as a decisive break in Ehrlich's life than it has been hitherto. He tried to use the laboratory, his most important work place, as a starting point to rebuild the old system. Under Koch, he organized and performed clinical trials after 1895. But Ehrlich had to reorientate. He needed to achieve a secure position within the rigid framework of institutionalized German medicine, which was mainly university based. This objective was complicated by his Jewish faith, and he had to grasp Behring's and then Althoff's offers. But Ehrlich remained indebted to the ideas of Julius Cohnheim on functional (experimental) pathology as related to clinical problems. ${ }^{138}$ In Germany, where the older medical disciplines were well established from about 1900, this meant sitting between the chairs of pathology on one side and clinical disciplines on the other. Although burdened with problems, Ehrlich made rigorous efforts to initiate the testing of dyes with the help of clinical colleagues even after he started to work in earnest on the side-chain and receptor theory. These efforts were not successful, and in this situation the theoretical evidence of his approach became more important than ever. In his institute, Ehrlich concentrated on constructing a comprehensive theory, not only of immunological processes but also of the human metabolism in general. The final aim continued to be the practical application to man, based on laboratory research. But at first, Ehrlich was contrained to satisfy himself, the scientific community and the public with vague assumptions about the future effectiveness of his concept in modern medicine. The critics of the side-chain and receptor theory, who raised their voices shortly after Ehrlich had developed his ideas, stimulated the further

${ }^{135}$ Georg Joannovics, 'Paul Ehrlich 1854-1915', Wiener Klinische Wochenschrift, 1915, 28: 937-42, esp. p. 940.

${ }^{136}$ Münch and Biel, op. cit., note 112 above, pp. 13-14.
${ }^{137}$ Parascandola, op. cit., note 11 above, esp. p. 30. See also Ehrlich's papers on chemotherapy, especially the Harben Lectures of 1907, in Himmelweit (ed.), vol. 3 , op. cit., note 4 above.

${ }^{138}$ Jokl, op. cit., note 5 above, pp. 972-4. 


\section{Paul Ehrlich and his Receptor Concept}

consolidation of his theory, and they dragged Ehrlich more and more into the pluralistic receptor world. The development of the receptor concept was, therefore, a construction dependant on the combination of events in his private and public life and in his academic career. This analysis corresponds with recent biographical research in general historiography which has tried to explain the life of scientists on the basis of their social and cultural environment. ${ }^{139}$

This revisionist account of Ehrlich and his receptors helps us to understand why his receptor theory was not at once generally accepted in pharmacology and it complements the existing literature on the history of pharmacology. ${ }^{140}$ Ehrlich's receptor concept was basic research, hard to understand, and its technical possibilities in his time were limited. But there are other reasons. Despite his reputation, Ehrlich was no pharmacologist and he did not agree with the mainstream of pharmacological research. This was devoted mainly to physical or physico-chemical views of the character of drug-binding. It was based on the idea of a mechanical connection between dye-stuff and cell. For pharmacologists such as Walther Straub (1874-1944), one of the most prominent German pharmacologists in the first half of the twentieth century, such physical properties as solubility and surface tension played a principal role in the effect of a substance on a cell. Arthur Cushny (18661926), one of the most internationally influential pharmacologists at the turn of the century, at least restricted the impact of structural chemistry in terms of a physico-chemical view. ${ }^{141}$ Above all, the doubts of contemporary pharmacologists were fuelled by the theoretical character of Ehrlich's ideas, ${ }^{142}$ which could be promoted only with the help of a vast propaganda apparatus. Although the side-chain theory delivered the basis for Ehrlich's own research on cancer and chemotherapy, ${ }^{143}$ and was seen by colleagues as an inspiration for further work, there was at first no evidence for its usefulness to immunology or pharmacology in general. ${ }^{144}$ As a construction, which came into existence as a product of Ehrlich's social biography, his personality and his scientific career development, the

\footnotetext{
${ }^{139}$ Margit Szöllösi-Janze, Fritz Haber, 1868-1934. Eine Biographie, Munich, Beck, 1998. See above all the introduction on pp. 9-22; idem, 'LebensGeschichte-Wissenschaftsgeschichte. Vom Nutzen der Biographie für Geschichtswissenschaft und Wissenschaftsgeschichte', Berichte zur

Wissenschaftsgeschichte, 2000, 23: 17-35; Christoph Gradmann, 'Leben in der Medizin: Zur Aktualität von Biographie und Prosopographie in der Medizingeschichte', in Norbert Paul and Thomas Schlich (eds), Medizingeschichte, Aufgaben, Probleme, Perspektiven, Frankfurt and New York, Campus, 1998, pp. 243-65.

${ }^{140}$ See Parascandola and Jasensky, op. cit., note 2 above; Parascandola, op. cit., note 2 above.

141 John Parascandola, 'The controversy over structure-activity relationships in the early twentieth century', Pharm. Hist., 1974, 16: 54-63, esp. pp. 55-6.

${ }^{142}$ This was registered already by contemporaries, see, for example, 'Obituary. Wirklicher Geheimrat Paul Ehrlich', Lancet, 1915, i: 525-6, esp. p. 525. It is considered also in the secondary literature on the receptors; see, for example, Rubin, op. cit., note 102
}

above, pp. 400-7; Cambrosio, Jacobi, and Keating, op. cit., note 114 above, pp. 662-99.

${ }^{143}$ Ehrlich saw the side-chain theory as a "unifying bond" (einigendes Band) of the work of all departments in the Frankfurt Institute. See Ehrlich, op. cit., note 131 above, p. 251. See also 'Paper on the cancer research of Ehrlich', anonymous, Frankfurt, 7 April 1906, in Nachlass Althoff A I, GstA PK. VI. HA, Rep. 92, No. 258, pp. 32-8, here esp. pp. 37-8; Lenoire, op. cit., note 22 above, pp. 79-82.

${ }^{144}$ See Paul Ehrlich and Hans Sachs, 'Kritiker der Seitenkettentheorie im Lichte ihrer experimentellen und literarischen Forschung. Ein Kommentar zu den Arbeiten von Bang und Forssmann' (Münchener Medizinische Wochenschrift, 1909), in Himmelweit (ed.), vol. 2, op. cit., note 4 above, pp. 448-63; Paul Ehrlich and Hans Sachs, 'Ist die Ehrlichsche Seitenkettentheorie mit den tatsächlichen Verhältnissen vereinbar? Bemerkungen zu der II. Mitteilung von Bang und Forssmann' (Münchener Medizinische Wochenschrift, 1910), in ibid., pp. 464-71; Paul Ehrlich to Friedrich Althoff, 18 Mar. presumably 1907, in Nachlass Althoff B, GstA PK. VI. 


\section{Cay-Rüdiger Prüll}

receptors were the final stage of a process spiralling up into the enterprise of theoretical research. With his propaganda management and his experimental system, Ehrlich was able successfully to adapt the hypothetical receptor system to every new challenge. The decision whether to join Ehrlich or to oppose him, whether to be a "pluralist" or a "unitarian", had parallels with religious profession. One had to believe in "the theory" or to abandon it totally. ${ }^{145}$ It was very much shaped by its creator, who tried to increase its credibility through a combination of persuasion and force. At this point, it could not be foreseen that the "discovery" of the receptors would become so central to pharmacology, and biomedicine in general, after 1945 .

HA, Rep. 92, No. 33, p. 329. Although the basic idea of chemical specificity survived in immunology after the death of the master, this was not true in general for his whole receptor concept. This remained controversial as Ehrlich's mature theory could not be used to explain the action of the living organism, see Mazumdar, op. cit., note 65 above, pp. 18-21; also
William Bulloch, The history of bacteriology, 2nd ed., London, Oxford University Press, (1938) 1960, pp. 275-9.

${ }^{145}$ See also August Wassermann, 'Paul Ehrlich', Münchener Medizinische Wochenschrift, 1909, 56: 245-7, esp. 247. 